Western University Scholarship@Western

Obstetrics \& Gynaecology Publications

Obstetrics \& Gynaecology Department

$5-1-2001$

Regulation of blastocyst formation.

A J Watson

L C Barcroft

Follow this and additional works at: https://ir.lib.uwo.ca/obsgynpub

Part of the Obstetrics and Gynecology Commons

Citation of this paper:

Watson, A J and Barcroft, L C, "Regulation of blastocyst formation." (2001). Obstetrics \& Gynaecology Publications. 58.

https://ir.lib.uwo.ca/obsgynpub/58 


\title{
REGULATION OF BLASTOCYST FORMATION
}

\author{
Andrew J. Watson and Lisa C Barcroft
}

Departments of Obstetrics and Gynaecology and Physiology, The University of Western Ontario, London, Ontario Canada, N6A $5 C 1$

\section{TABLE OF CONTENTS}

\section{Abstract}

2. Introduction

3. Preimplantation Development

3.1. Oogenetic to Embryonic Transition

3.2. Compaction

3.3. Blastocyst Formation (Cavitation)

4. Trophectoderm Differentiation

4.1. Cell Polarity and the Inside Outside Hypothesis

4.2. Cell-to Cell adhesion

4.3. Establishment of Trophectoderm Tight Junctions

5. Na/K-ATPase and Blastocyst Formation

5.1. Isoform expression in the mouse embryo

5.2. Isoform expression in the cow embryo

5.3. Ouabain sensitivity and Enzyme activity

5.4. Role of Na/K-ATPase in Cavitation

5.5. Murine Knock-outs

6. Water transport and Blastocyst Formation

6.1. Aquaporins

6.2. Aquaporin Expression and Function During Blastocyst Formation

7. Summary and Model of Blastocyst Formation

8. References

\section{ABSTRACT}

Preimplantation or pre-attachment development encompasses the "free"-living period of mammalian embryogenesis, which directs development of the zygote through to the blastocyst stage. Blastocyst formation is essential for implantation, establishment of pregnancy and is a principal determinant of embryo quality prior to embryo transfer. Cavitation (blastocyst formation) is driven by the expression of specific sets of gene products that direct the acquisition of cell polarity within the trophectoderm, which is both the first epithelium of development and the outer cell layer encircling the inner cell mass of the blastocyst. Critical gene families controlling these events include: the E-cadherin-catenin cell adhesion family, the tight junction gene family, the $\mathrm{Na} / \mathrm{K}$ ATPase gene family and perhaps the aquaporin gene family. This review will update the roles of each of these gene families in trophectoderm differentiation and blastocyst formation. The current principal hypothesis under investigation is that blastocyst formation is mediated by a trans-trophectoderm ion gradient(s) established, in part, by $\mathrm{Na} / \mathrm{K}$-ATPase, which drives the movement of water through aquaporins (AQPs) across the epithelium into the extracellular space of the blastocyst to form the fluid-filled blastocoel. The trophectoderm tight junctional permeability seal regulates the leakage of blastocoel fluid, and also assists in the maintenance of a polarized $\mathrm{Na} / \mathrm{K}$ ATPase distribution to the basolateral plasma membrane domain of the mural trophectoderm. The cell-to-cell adhesion provided by the E-cadherin-catenin gene families is required for the establishment of the tight junction seal and the maintenance of the polarized $\mathrm{Na} / \mathrm{K}$-ATPase distribution. Blastocyst formation is therefore directly linked with trophectoderm cell differentiation, which arises through fundamental cell biological processes that are associated with the establishment of cell polarity.

\section{INTRODUCTION}

"This chapter is dedicated to the spirit of Lynn Wiley whose research accomplishments provided great insight into the regulation of blastocyst formation and inspired others to pursue this exciting research area as well"

The first week of development represents a perilous time for the early conceptus as the majority of inseminated oocytes fail to successfully complete this developmental interval to implant to the uterine wall and establish a pregnancy (1-5). This interval called preimplantation or pre-attachment development (depending upon the species) is uniquely mammalian and encompasses the free-living period of mammalian development during which the early conceptus traverses the oviduct and gains access to the uterine environment (1-6). This period culminates in the formation of an embryonic structure called the blastocyst, which is composed of the outer epithelial trophectoderm, a fluid-filled cavity and small group of cells called the inner cell mass, which are the 
progenitors of the embryo proper (6-12). The blastocyst is not simply the vessel that delivers its cargo of inner cell mass cells to the uterus as it contains the specialized cell type (the trophectoderm), which will mediate the maternalfetal interactions required to support eutherian embryogenesis. The trophectoderm cells differentiate into the trophoblast to mediate either invasion or attachment to the uterus during implantation and as a prelude to their subsequent contribution to placental structures (6-12). Blastocyst formation is therefore essential for the establishment of pregnancy and is intimately coordinated by the events controlling trophectoderm differentiation.

Decades of research have elucidated many of the cell biological and molecular mechanisms that control this developmental interval. Although the mouse embryo has been the animal model of choice for most of the experimentation, the extension of these studies to the human and domestic agricultural species has stimulated vigorous research activity in these embryo systems leading to explosive growth in the fields of assisted reproductive technology and embryo transfer in humans and other species (1-12). Despite these advances, pregnancy rates following embryo transfer remain lower than expectations for all species, and further advances are required to optimize the general application of these technologies (16). Areas of research include; ovarian stimulation; folliculogenesis and oocyte maturation; embryo culture and metabolism; hormonal and growth factor regulation; gamete micromanipulation (intracytoplasmic sperm injection; ooplasmic injection); genomics and gene expression; uterine receptivity and synchronization; embryonic signaling of maternal recognition of pregnancy; organ, gamete and embryo cyropreservation and embryo cloning, transgenesis, and gene targeting in animal species.

The purpose of this review is to outline the critical events in the early developmental program that regulate blastocyst formation. It is hoped that by reviewing this important research area, specific avenues for further research will be revealed supporting a greater understanding of the mechanisms controlling preimplantation or pre-attachment development. This information is required to promote the safe and efficient production of normal mammalian embryos and offspring in assisted reproductive technology and embryo transfer applications.

\section{PREIMPLANTATION DEVELOPMENT}

Development begins during gametogenesis within the ovaries and testes of the parental animals. The spermatozoon contributes one set of paternal chromosomes to the embryo at the time of fertilization. The maternal chromosomes of the ovulated oocyte arrest at metaphase II following ovulation to await insemination by a fertilizing spermatozoa. Following fertilization, the zygote undergoes several cleavage divisions that divide the ooplasm into smaller compartments or blastomeres. The first morphogenetic event, compaction, arises following the third cleavage division in the mouse, although the timing of this event varies greatly among the mammalian species arising, for example, at the 32-64 cell embryo stage in the bovine embryo $(4,13-17)$. Compaction represents the onset of cellular differentiation during mammalian development as the outer cells of the conceptus begin to polarize as a prelude to trophectoderm differentiation $(7,17,18)$. Blastocyst formation is the morphogenetic event that follows compaction in this continuum of preimplantation development (1-12). Each succeeding phase of this developmental interval is dependent upon preceding events. It is therefore not possible to consider the mechanisms controlling blastocyst formation by focusing exclusively on the blastocyst. We will begin by briefly examining the oogenetic to embryonic transition and compaction.

\subsection{Oogenetic to Embryonic Transition}

Mammalian development is initially sustained by gene transcripts and polypeptides produced and stored in the oocyte during oogenesis (19). After one to several cleavage divisions (depending upon the species), genetic control of development comes predominantly under the embryo's control as oogenetic gene products decline, and embryonic transcription begins (19-29). The transition from oogenetic to embryonic control of development or maternal zygotic transition (MZT) varies in its timing between species $(4,22,30)$. This is a critical event as blastocyst formation is dependent on expression of embryonic genes (31-33). However, it must also be kept in mind that specific oogenetic products (for example E-cadherin) can influence development to at least the blastocyst stage and potentially later in development. Since this topic is the subject of several reviews (for example 19, 22, 30, 34, 35) including a chapter in this issue only the principal components will be briefly summarized. Mouse embryos cultured from the one-cell stage in the presence of transcriptional inhibitors do not develop beyond the two-cell stage, indicating that new transcription from the zygote genome is, necessary for development beyond this point (19-29). During this transition, the majority of maternal mRNA molecules accumulated during oogenesis are degraded and replaced by new mRNA molecules $(20-24,28,36)$. These fluctuations in mRNA populations parallel marked changes in protein synthetic patterns between the 1- to 4-cell stages $(27,33,35,37)$. Similar observations have been obtained from studies applied to other species however the timing may be delayed compared to the mouse $(38,39)$. For example, $\left({ }^{3} \mathrm{H}\right)$-uridine incorporation was first detected at the end of the bovine eight-cell stage $(38,39)$. However, lower levels of $\left({ }^{3} \mathrm{H}\right)$-uridine incorporation have been reported in two- and four-cell bovine embryos suggesting that a minor degree of transcriptional activity precedes the larger full activation of the embryonic genome (37, 38, 40, 41). This may in fact be a characteristic of all species. Bovine embryos cultured from the one- to four cell stages in the presence of alpha-amanitin, progress to the four/eight-cell stage but none develop to the 16-cell stage $(42,43)$.

Many of the transcripts expressed at the 2-cell stage of mouse development continue to accumulate as development progresses to the blastocyst stage. However, there are a number of additional transcripts important for cell proliferation, compaction, and blastocoel formation 


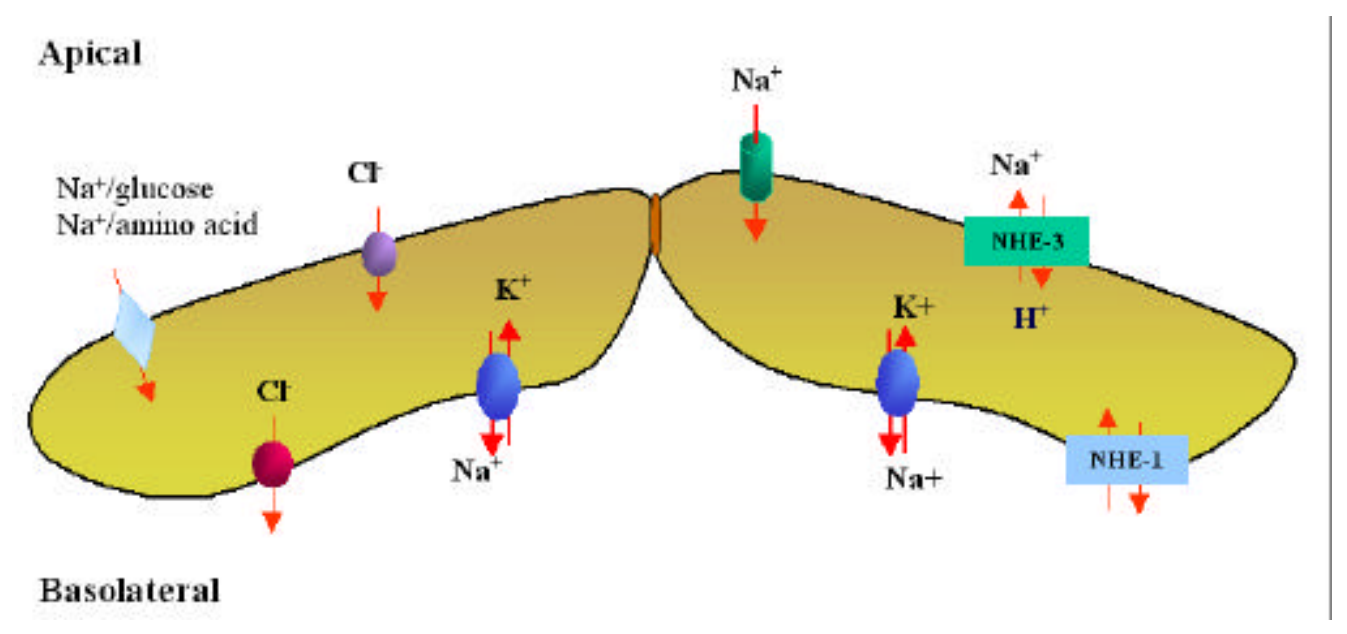

Figure 1. Expression of ion transporters and enzymes in the trophectoderm of mammalian preimplantation embryos.

(cavitation) that are not expressed until after the 2-cell stage $(33,35)$. The morphological changes in embryos that are necessary for blastocyst formation are in fact tightly coupled to ongoing transcriptional events (26). The variation in the patterns of newly synthesized polypeptides observed on two-dimensional gels between the 4-cell to blastocyst stage are not as marked as those between the 1to 4-cell embryo stages, but several new gene products undergo a transcriptionally-dependent increase during this interval (44).

\subsection{Compaction}

Compaction is a common feature of preimplantation development within all eutherian mammalian embryos, although the timing of this event varies greatly arising later in the pre-attachment embryos of the agricultural domestic species (4). Compacting embryos undergo an increase in interblastomeric contact that obscures the distinct individual cell boundaries and continues until the embryo ultimately appears as a uniform cell mass called a morula $(7,14-17)$. The cellular events associated with compaction include: (i) the development of $\mathrm{Ca}^{2+}$ dependent cell adhesion; (ii) the establishment of gap junction mediated interblastomeric cell communication; (iii) the initiation of cell contact-induced cell polarization, and (iv) the appearance of focal tight junctions which eventually divide the plasma membrane of the outer blastomeres into apical and basolateral membrane domains (15-17). These events, particularly the development of asymmetrical cell contact and polarity within the outer blastomeres are essential and directly contribute to the formation of the blastocyst. By the late morula stage, the embryo acquires the remaining macromolecules that are necessary for blastocyst formation (cavitation) to occur (31-33).

\subsection{Blastocyst Formation (Cavitation)}

The trophectoderm acquires the capacity to initiate and regulate the events of cavitation by expressing gene products that facilitate the transport and retention of the blastocoelic fluid as it accumulates in the nascent blastocyst cavity. Therefore, for cavitation to arise, the embryo relies upon the development of a polarized epithelium $(6-8,11,12)$. The blastocoelic fluid is predominantly water, thus the mechanism of its production and accumulation relies on the ion transport properties of the trophectoderm $(12,45-48)$. In many ways, the trophectoderm is comparable to an early kidney tubule epithelium as many ion and water transport characteristics are shared between these epithelia. The trophectoderm is an ideal model for epithelial cell differentiation as this epithelium arises "de novo" from apolar blastomeres. For these reasons blastocyst formation is tightly coupled to the development of trophectoderm ion transport systems, the epithelial junctional complex, and the primary role played by establishment of cell-to-cell adhesion between blastomeres during compaction (6-8, 11, 12; see Figure 1).

The basis for these conclusions stemmed initially from isotope flux measurements and electron probe microanalysis of $\mathrm{Na}^{+}, \mathrm{Cl}^{-}, \mathrm{K}^{+}, \mathrm{Ca}^{2+}$, and $\mathrm{Mg}^{2+}$ in the murine blastocyst fluid (49-55). These studies demonstrated that all of these ions were concentrated within the blastocoelic fluid (49-55). Active transport would be required to move these ions against their concentration gradients. The transport of amino acids such as glycine and alanine is also linked to a sodium-dependent mechanism that develops in the blastocyst (54-58). The vectorial transport of $\mathrm{Na}^{+}$and $\mathrm{Cl}^{-}$(but not $\mathrm{K}^{+}$) from the medium is essential for the onset and progression of cavitation (52). The $\mathrm{Na}^{+}$ions likely enter the trophectoderm cells through apically localized $\mathrm{Na}^{+}$channels and/or via various $\mathrm{Na}^{+}$co-transporters such as the $\mathrm{Na}^{+} / \mathrm{H}^{+}$exchanger (52) or $\mathrm{Na}^{+} /$glucose co-transport system (59). The $\mathrm{Cl}^{-}$transport was initially thought to be paracellular, and thus regulated by the epithelial junctional complex (52). More recent studies have determined that $\mathrm{Cl}$ transport is also mediated across the epithelium $(47,48$, $60)$. It has been proposed that the trans-trophectoderm $\mathrm{Na}^{+}$ gradient is completed by the active transport of $\mathrm{Na}^{+}$out of the cell into the blastocoelic cavity by a basolaterally localized $\mathrm{Na} / \mathrm{K}$-ATPase $(9,60,62)$. The presence of such a gradient would result in the movement of water down the gradient across the epithelium and into the blastocyst cavity $(6,8,11,62)$. A great deal of evidence collected in the past 
twenty years supports this hypothesis as it has been determined that the $\mathrm{Na} / \mathrm{K}$-ATPase is present in the basolateral plasma membrane domain of the trophectoderm for several species including the mouse, rabbit, pig, and cow $(6-12,31,46,52,55,61-75)$.

Cavitation is thus a complex cellular process that requires the precise coordination of several cellular events. $\mathrm{Na} / \mathrm{K}$-ATPase distribution is influenced by the stability of the trophectoderm tight junctional seal (76-84); the membrane cytoskeleton (79) and by E-cadherin mediated cell adhesion $(67,85-87)$. We will now turn our attention to the establishment of cell polarity in the outer embryonic blastomeres as this event not only drives trophectoderm cell differentiation but also is the foundation of blastocyst formation.

\section{TROPHECTODERM DIFFERENTIATION}

\subsection{Cell Polarity and the Inside Outside Hypothesis}

Cell polarity in the preimplantation embryo is characterized by the establishment of; (1) cell surface components such as apical microvilli and associated lectin receptors (reviewed by (88), (2) asymmetrical distributed of membrane proteins between the apical and basolateral plasma membrane domains $(6,12)$, and (3) specific cytoplasmic components (ie. the apical aggregation of actin bundles and endocytic vesicles; (88)) and the basal migration of mitochondria and lipid vesicles (9). As interblastomeric cell-to-cell contact increases during compaction, the formation of "free" and "apposed" plasma membrane regions occurs and by the 16-cell stage, the mouse embryo is composed of an outer layer of polar cells that completely encloses an inner group of 4-7 apolar blastomeres. The degree of cell contact associated with cell position provides the necessary developmental cue for the maintenance of polarity within the outer blastomeres (for review see (17). The "free" or apical membrane surfaces of the outer blastomeres develop a cytochalasin-D resistant microvillus cap (80), $\mathrm{Na}^{+}$-dependent amino acid transport systems (57), a Na${ }^{+}$/glucose co-transporter (59) and $\mathrm{Na}^{+}$channels (52). The basolateral surfaces of the outer blastomeres remain free of microvilli but become distinguished from the apical surfaces by the localization of the tight junction ZO-1 polypeptide (84), gap junctions (87), and E-cadherin (uvomorulin; (90)). The polarity exhibited by the outer blastomeres is displayed within the cell cortex by the appearance of an apical actin cap and within the cytoplasm by the asymmetric distribution of lipid vesicles, mitochondria and the nucleus towards the basal poles of the cells $(8,91)$. This cell polarity is very stable, as it is maintained even in the presence of inhibitors (such as cytochalasin B or D) that block the cell flattening, the development of cell adhesion, and the establishment of cell coupling via gap junctions (16). Although asymmetrical cell contact is the principal spatial cue in the development of trophectodermal cell polarity (reviewed by (88)), directional ion currents have also been implicated. Nuccitelli and Wiley (92) showed that individual polarized morula stage blastomeres exhibit a positive current flowing through their apical end and out their basal end. The ion current polarization hypothesis suggests that an asymmetry in inward current between the free and apposed cell surfaces could facilitate cell polarization $(10,92)$. This current may interact with the cytoskeleton via the plasma membrane to polarize the cellular positions of the nucleus and mitochondria to the basal cell ends (8).

\subsection{Cell-to Cell adhesion}

E-cadherin (uvomorulin) is the principal molecular component of the adherent junction. Stable cellto-cell contacts and adhesion plaques arise through associations of E-cadherin with the actin cytoskeleton mediated by interactions with alpha-catenin, beta-catenin and gamma-catenin (93-96). The pivotal role played by Ecadherin during epithelial differentiation has been demonstrated by transfection of non-epithelial cell lines with cadherins to induce a polarized epithelial phenotype (93). Cells transfected with the brain-associated cadherin, B-cadherin, do not polarize (93). E-cadherin is at the top of the cascade of protein interactions that drive trophectoderm cell differentiation. E-cadherin, and catenins, as well as cytoskeletal actin are expressed and stored in the oocyte during oogenesis; therefore, they are present in the early mammalian embryo from fertilization onward (97, 98). However, stable E-cadherin mediated cell-to-cell adhesion does not arise until compaction is initiated $(87,99,100)$. The factors or mechanisms that control the suppression of stable cell-to-cell adhesion in the early embryo prior to compaction represent a new area of research that requires further attention.

The dependence of compaction and cavitation upon E-cadherin mediated events has been demonstrated by treating pre-compaction murine embryos with E-cadherin blocking antisera $(64,67,85)$. Embryos treated with an antibody to E-cadherin do not undergo compaction and do not proceed with a normal cavitation (67). Under these conditions, the epithelial junctional complex does not form. It appears that E-cadherin, possibly working in concert with the membrane cytoskeleton, contributes to the establishment of the epithelial junctional complex and the insertion of $\mathrm{Na} / \mathrm{K}$-ATPase into the basolateral membranes. More recently, gene-targeting approaches by homologous recombination methods have been employed to produce Ecadherin null mutants $(101,102)$. E-cadherin null embryos undergo compaction (an event contributed to residual oogenetic E-cadherin proteins) but fail to develop into normal blastocysts and never hatch from the zona pellucida (101, 102). Removal of E-cadherin does not prevent cell polarization but rather delays and randomizes the orientation of cell polarity preventing the formation of an ordered trophectoderm cell layer $(101,102)$. Further analysis of these null mutant embryos revealed that both alpha- and beta-catenin are down regulated and that ZO-1 expression is not detectable (103). These studies clearly demonstrate that E-cadherin plays a pivotal role in differentiation of the trophectoderm, and thus has a central role in supporting further embryonic development (see figure 2).

Similarly, the trophectoderm epithelium of alphacatenin null mutants is abnormal, and development is halted at the early blastocyst stage (97). In contrast, murine 

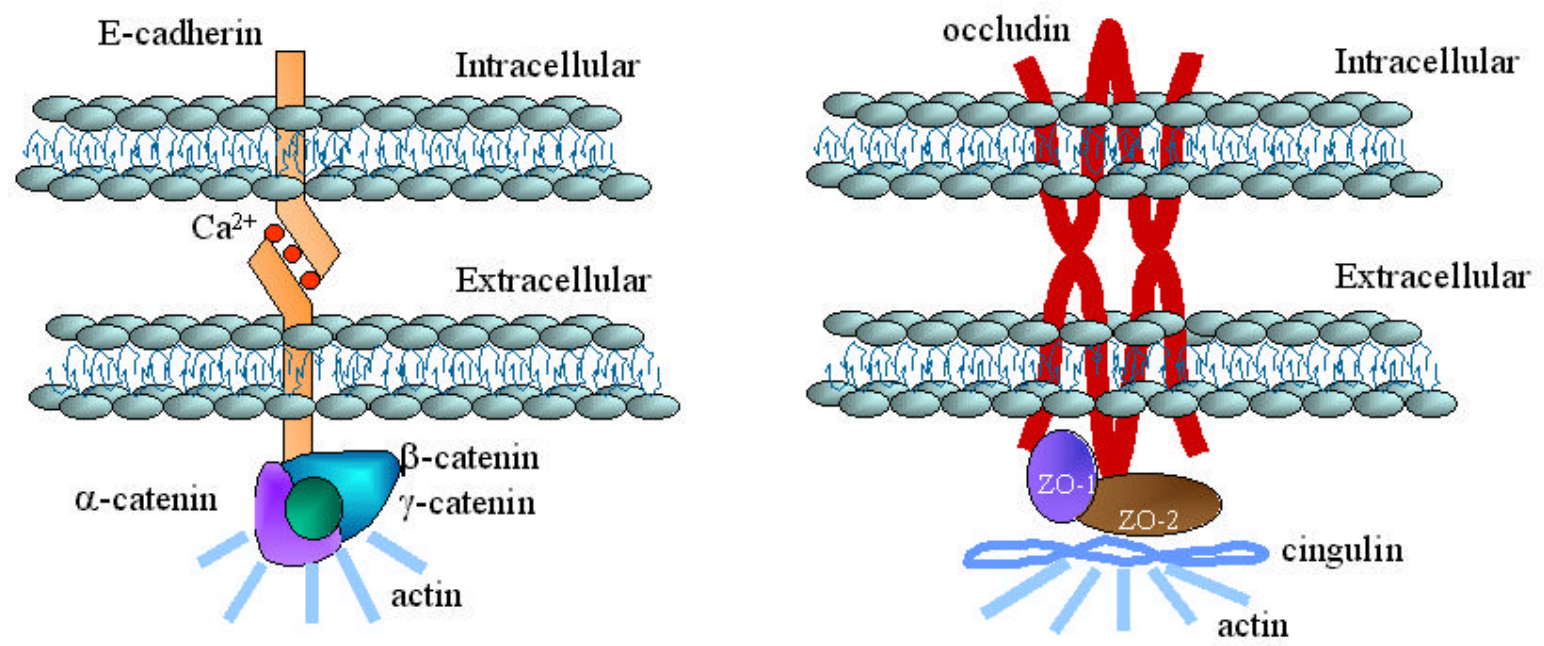

Figure 2. Molecular organization of the zonula adherens (left side) and zonula occludens (right side) in polarized epithelial cells.

beta-catenin null mutants undergo cavitation and continue to develop until gastrulation (100). Maternal (oogenetic) stores of beta-catenin may suffice during these early events and/or gamma-catenin, may also bind to the cytoplasmic domain of E-cadherin, mediating interactions with alphacatenin (104-106). It follows that two distinct Ecadherin/catenin complexes occur within the same cell, specifically, E-cadherin/beta-catenin and E-cadherin/ gamma-catenin (81). Gamma-catenin, is the only known protein shared by desmosomes and adherens junctions (AJs) (81). Development of gamma-catenin null mutants generally ceases at day 10.5 of gestation $(101,105)$. Embryonic gamma-catenin is synthesized from the murine 8-cell stage onward, but the protein does not become localized to cell membranes until the morula stage (following compaction), where it is present in all membrane contact sites, including those of the inner cell mass (81). Thus, although all components of the AJ are implicated in compaction and trophectoderm differentiation, their roles are variable.

Adherens junctions (AJs) tightly regulated, yet dynamic structures, given that movement requires constant disruption of some cell contacts with formation of new ones, without overall loss of adhesive strength. The presence of AJ components in a developing oocyte suggests that a secondary programming step is required to either trigger or block inhibition of their association. A viable hypothesis for the delay of $\mathrm{AJ}$ formation in the early mouse embryo is that an inhibitor or repressor of Ecadherin/catenin interactions represses the establishment of stable adhesion complexes. Recent studies have revealed a potential role for IQGAPs, targets of the Rho GTPases (Cdc42 and Rac1) in inhibition of E-cadherin/catenin interactions (107-111). IQGAP1 binds to the amino terminus of beta-catenin complexed with E-cadherin in vivo and in vitro, promoting dissociation of alpha-catenin, thereby disrupting cadherin-mediated cell adhesion (108111).
The Rho GTPases are 20-30 kDa GTP-binding proteins that belong to the Ras superfamily. Rho GTPases include Rho $\mathrm{A}, \mathrm{B}, \mathrm{C}, \mathrm{D}$, and $\mathrm{E}, \mathrm{Rac} 1$ and 2, RacE, Cdc42Hs and TC10 (112-115). RhoA, Cdc42 and Rac1 have been most extensively studied. These three GTPases regulate membrane ruffling, cell motility, actin polymerization and cell-cell adhesion (112-115). Rho activity is modulated in a cyclical fashion. Effectively, these small GTPases act as molecular switches, alternating between active GTP-bound and inactive GDP-bound states. The latter may be promoted by GTPase activating proteins (GAPs), such as Rho GAP, which down-regulates GTPase activity. Recent studies in keratinocytes and other epithelial cells have determined that Rho GTPases are also involved in the regulation of cadherin mediated cell-cell adhesion $(109,110,113,116,117)$. This conclusion is further supported by reports that demonstrate that over expression of dominant-negative $\mathrm{Cdc} 42$ and/or Rac1 reduces cadherinmediated cell-cell adhesion $(109,110)$.

A number of $\mathrm{Cdc} 42$ and Rac1 effecter proteins have been identified. Of these, only IQGAPs are implicated in the regulation of cell adhesion. Two IQGAP forms (1 and 2) are known. These large (>180 kD) proteins appear to serve as scaffolds, and contain several specific protein interacting domains, including a calponin-related F-actin binding segment, a WW domain, four calmodulin IQ motifs, and 5-6 IQGAP repeats, the function of which has not been determined $(112,113-116)$. They lack an arginine finger residue in their Ras GAP domain, and may not have significant GAP activity $(109,110)$. Both IQGAPs interact with $\mathrm{Cdc} 42$ and Rac1 to inhibit their GTPase activity; thus maintaining them in an active, GTP-bound state (108-111, 116-122). The interaction of Cdc42 or Rac1 with IQGAP1 inhibits it from binding to beta-catenin. This allows alphacatenin to associate with beta-catenin, stabilizing cadherinmediated adhesion $(109,110)$. Although these interactions of cadherins/catenins/Rho GTPases and IQGAPs have not as yet been explored during the first week of development 


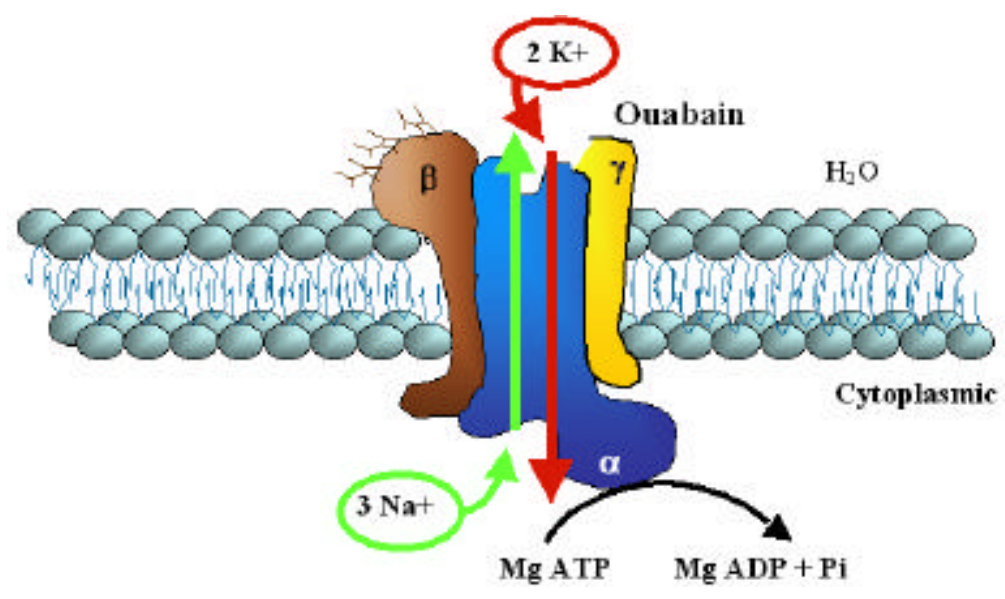

Figure 3. Structure and characteristics of the Na/K-ATPase.

we would predict that this area of research would be fruitful for revealing the mechanisms that trigger the onset of stable cell-to-cell adhesion and thus the onset of compaction and cell polarity in outer blastomeres during preimplantation development.

\subsection{Establishment of Trophectoderm Tight Junctions}

The tight junction (or zonula occludens) consists of a complex of several proteins including ZO-1, ZO-2, $7 \mathrm{H} 6$, cingulin, occludin and claudins (123; see figure 2). The zonula occludens appears as a series of close membrane contacts or "kisses" (84). In freeze-fracture the junction forms a series of anatomizing fibrils (reviewed by $(124,125))$. Occludin and the claudins are the core integral membrane proteins that interact with ZO-1 (a $220 \mathrm{kDa}$ peripheral membrane protein) and cingulin to form a link between the tight junction and the cytoskeleton (123-129). The tight junction serves at least two functions, these being the regulation of paracellular transport (the movement of water and solutes between epithelial cells) and maintenance of epithelial cell polarity. These roles are first revealed during trophectoderm cell differentiation and blastocyst formation $(130,131)$. The development of the junctional complex is initiated within the 8-cell embryo but requires an additional two cleavage divisions to become complete in the blastocyst $(76-78,84)$. The impermeable seal does not form until after cavitation has begun and it is only after the formation of this seal that the leakage of blastocoelic fluid is regulated, allowing the embryo to expand in size due to fluid accumulation (77). The epithelial junctional complex, along with the membrane cytoskeleton, almost certainly contributes to the maintenance of the polarized $\mathrm{Na} / \mathrm{K}$ ATPase distribution within the trophectoderm (67). If the junctional complex and the cortical actin cytoskeleton are disrupted by the incubation of mouse blastocysts in medium containing cytochalasin $\mathrm{B}$ or $\mathrm{D}$, the $\mathrm{Na} / \mathrm{K}$-ATPase polarized basolateral distribution is also disrupted and the enzyme assumes an apolar distribution encircling the outer margins of the trophectoderm cells (67). These embryos can recover and proceed normally through cavitation if they are subsequently cultured in medium without cytochalasin. This experiment demonstrates that cavitation is dependent upon the epithelial junctional complex and the cortical cytoskeleton, perhaps due to their role in maintaining the basolateral distribution of the $\mathrm{Na} / \mathrm{K}$-ATPase and polarity of other transporters as well. ZO-1 polypeptides are not detectable by immunofluorescence in early cleavage stage bovine embryos until the morula stage in differentiating outer blastomeres (132). The ZO-1 distribution pattern consists of a thin band confined to the apical contact points between adjacent outer cells of morulae and blastocysts (132). These observations parallel findings in the early mouse embryo in which ZO-1 protein is first localized at contact sites between outer blastomeres following compaction (133). Recently it has been demonstrated that ZO-1 alphat isoform proteins first appear in compacting mouse morulae as perinuclear foci followed by membrane accumulation between the outer blastomeres (134). The establishment of zonular ZO-1 localization (59) and tight junction formation coincides with the onset of cavitation (133-135).

\section{Na/K-ATPase AND BLASTOCYST FORMATION}

$\mathrm{Na} / \mathrm{K}$-ATPase is a primary driver of $\mathrm{Na}^{+}$and water re-absorption in the kidney and is essential for the maintenance of body fluid and electrolyte homeostasis (136; see figure 3)). The enzyme establishes and maintains the high internal $\mathrm{K}^{+}$and low internal $\mathrm{Na}^{+}$concentrations found in eukaryotic cells (137-149). The enzyme actively transports $3 \mathrm{Na}^{+}$out of the cell and $2 \mathrm{~K}^{+}$into the cell for each molecule of hydrolyzed ATP. The electrochemical gradient that the $\mathrm{Na} / \mathrm{K}$-ATPase generates is necessary for maintaining osmotic balance, the resting membrane potential, and the excitable properties of muscle and nerve cells (137-140). The $\mathrm{Na}^{+}$gradient provides the energy for $\mathrm{Na}^{+}$-coupled transporters that mediate the translocation of ions $\left(\mathrm{H}^{+}, \mathrm{Ca}^{2+}, \mathrm{Cl}^{-}, \mathrm{PO}_{4}^{-}\right)$, substrates (glucose and amino acids) and neurotransmitters (136). The catalytic alphasubunit of $\mathrm{M}_{\mathrm{r}} 100 \mathrm{kD}$ is responsible for ion transport (139145). The beta-subunit of $M_{r} 40-60 \mathrm{kD}$ facilitates the processing and insertion of the alpha-subunit into the plasma membrane $(138,145)$. In mammals these subunits are encoded by multi-gene families consisting of four alpha subunit genes (alpha1, alpha2, alpha3, alpha 4) and three beta subunit genes (beta 1 , beta 2 , beta 3 ), each displaying a 

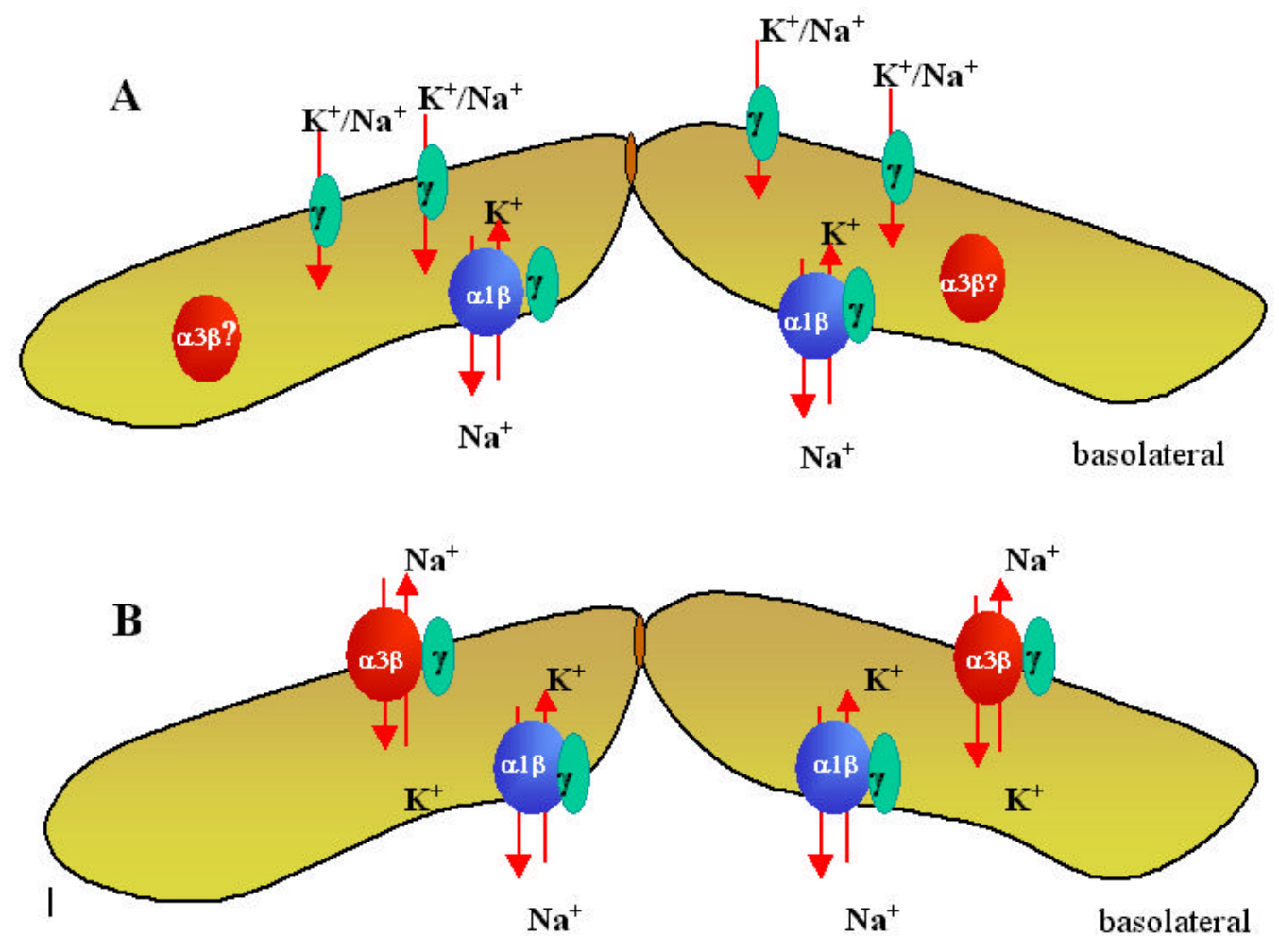

Figure 4. Differential expression of $\mathrm{Na} / \mathrm{K}-\mathrm{ATPase}$ subunit isoform protein in murine (A) and bovine (B) trophectoderm cells at the blastocyst stage.

distinct temporal and spatial expression pattern (139-146, 150-152). The gamma-subunit is a small (8-14 kD) hydrophobic peptide whose function is currently under investigation $(146,148,150)$.

The alpha1/beta1-isozyme makes up the ubiquitous isozyme found in nearly every tissue and is the predominant kidney isozyme $(137-149,153)$. The alpha 2 and alpha 3 isoforms are present in low abundance in the kidney; the alpha 2 isoform predominates in adipocytes, muscle, heart and brain, while the alpha 3 isoform is most abundant in the brain $(139,153)$. The alpha 4 isoform is testes-specific (144). The beta 2-isoform is present in muscle, pineal gland and nervous tissue while the beta 3 isoform is present in testes, retina, liver and lung (154-156). Why are so many $\mathrm{Na} / \mathrm{K}-\mathrm{ATPase}$ isoforms required? The most logical view on their diversity is that differences in cation and ATP affinity of each isozyme are essential for adapting $\mathrm{Na} / \mathrm{K}$-ATPase activity to specific physiological conditions (157). Isozymes of Na/K-ATPase, composed of different combinations of alpha and beta subunit isoforms, have unique properties and are subject to developmental and hormonal regulation (158-175). For example, the choice of beta subunit does not greatly influence the kinetic properties of the enzyme but can have an effect on $\mathrm{Na}^{+}$ affinity. Switching the alpha subunit significantly alters the affinity for $\mathrm{Na}^{+}, \mathrm{K}^{+}$and ATP as well as the enzyme's sensitivity to ouabain (potent and specific inhibitor of $\mathrm{Na} / \mathrm{K}$-ATPase activity). In rodents, the alpha 1 isoform is ouabain resistant compared to other alpha isoforms (172175).

\subsection{Isoform expression in the mouse embryo}

We initially detected $\mathrm{Na} / \mathrm{K}$-ATPase polypeptides by immunofluorescence at the late morula stage of mouse preimplantation development (62). Coincident with cavitation, the $\mathrm{Na} / \mathrm{K}$-ATPase immunofluorescence signal underwent a redistribution becoming restricted to the basolateral cell margins of the mural trophectoderm and its projections, overlying the inner cell mass $(62,83,176)$. These early studies were applied to sectioned material, and no immunofluorescence was detected within the inner cell mass or polar trophectoderm. These findings were at variance with other studies where $\mathrm{Na} / \mathrm{K}$-ATPase activity was reported in mouse oocytes and early cleavage stages be measuring ion flux $(49,50)$ and also by measuring ouabain sensitive ${ }^{86} \mathrm{Rb}^{+}$uptake in preimplantation stage embryos (53). We proposed that these methods were more sensitive than the immunofluorescence methods we initially employed and detected the " housekeeping" level of $\mathrm{Na} / \mathrm{K}$ ATPase activity present in all eukaryotic cells (177). We surmised that this low "housekeeping" level of the enzyme in the early cleavage stages increased in abundance to a level detectable by immunofluorescence in the late morula, just prior to the onset of cavitation (see figure 4). Additionally, Gardiner et al. (178) reported that both alpha and beta subunit polypeptides were detectable throughout preimplantation development by Western blot techniques. 
The results from these early studies certainly suggested that isoforms of both alpha and beta subunits were present throughout preimplantation development $(53,178)$ and that by the blastocyst stage at least one isoform of the enzyme increased in abundance and became confined to the basolateral regions of the mural trophectoderm (62). These studies also raised the possibility that additional isoforms of the enzyme subunits may be expressed during early development.

Transcript levels for $\mathrm{Na} / \mathrm{K}$-ATPase subunit isoforms were first examined by probing three identical Northern blots with ${ }^{32} \mathrm{P}$-labeled cDNAs encoding the three alpha-subunit isoforms of the rat Na/K-ATPase (66). The first reports characterizing the tissue distribution for the alpha 3-isoform within fetal brain and heart raised expectations that it may also be an "embryonic" isoform (139, 179-182). Northern hybridization experiments revealed the expression of alpha 1-isoform mRNAs throughout murine preimplantation development $(66,178)$. The hybridization signal displayed a pattern of mRNA expression that is typical for other mRNAs during mouse preimplantation development in which maternal mRNAs are subject to turnover and reduction in amount during the first cleavage division and later recover from the 2-cell stage, increasing in abundance through to the blastocyst (23-25, 28, 30, 35, 183). Watson et al. (66) reported a 43fold decrease in $\mathrm{Na} / \mathrm{K}$-ATPase alpha 1 -isoform mRNA between the zygote and 2-cell embryo stage. Gardiner et al. (178) reported a 45-fold increase in alpha-subunit mRNA from the 2-cell to the blastocyst stages. Following the 2-cell stage, the $\mathrm{Na} / \mathrm{K}$-ATPase alpha-1 subunit mRNA approximately doubles in abundance for every subsequent cleavage division, indicating that a relatively constant amount per cell is maintained (66).

Transcripts encoding the beta 1-subunit isoform accumulated in a very different manner throughout mouse preimplantation development (66). These transcripts were detected within zygotes but not in 2-, 4-, or 8-cell embryos by Northern blot analysis. Beta 1-subunit isoform mRNAs became detectable once again in morulae and underwent a further increase in abundance by the blastocyst stage (66). At first these results appeared to be at variance with the findings of Gardiner et al., (178) who reported the presence of the beta-subunit protein throughout preimplantation development by the technique of immunoblotting. Once again, the differences in sensitivity of methods used for these early studies proved to be the source of this apparent disparity. Both studies $(66,178)$ raised the possibility that the beta-subunit performs an essential role in coordinating the onset and progression of cavitation in the mouse embryo (see figure 4).

A more recent evaluation examining the presence of transcripts encoding the various subunit isoforms of the $\mathrm{Na} / \mathrm{K}$-ATPase employed the more sensitive reversetranscription-polymerase chain reaction (RT-PCR) method and demonstrated that indeed additional isoforms of the $\mathrm{Na} / \mathrm{K}$-ATPase are expressed throughout murine preimplantation development (74). mRNAs encoding the alpha 2-isoform were detected in oocytes but not in any preimplantation embryo stage, while mRNAs encoding the alpha 3-isoform were detected in oocytes and in each stage of preimplantation development from the 2-cell to the blastocyst stage (74). mRNAs encoding the alpha 4isoform were not detected in oocytes or during preimplantation development. In addition, this study reported that mRNAs encoding beta 2- and beta 3-isoforms were detectable throughout preimplantation development (74). These transcripts were not detected by Northern blot analysis (73), and thus do not likely accumulate to an appreciable level in the mouse. The presence of alpha 1and beta 1-polypeptides were reported throughout murine preimplantation development by employing wholemount confocal microscopy methods. However, polypeptides encoding the alpha 3-, beta 2 - and beta 3 -subunits while expressed, were not localized to cell margins in any preimplantation stage. This study has clarified many of the earlier discrepancies by determining that multiple isoforms of the $\mathrm{Na} / \mathrm{K}$-ATPase subunits are expressed throughout murine preimplantation development. However, a number of questions remain as it is certainly not clear as to why multiple isoforms are expressed; how their membrane localization is regulated; and whether each expressed isoform contributes to the program of preimplantation development and cavitation in a unique manner or not.

Recently Jones et al., (148) reported that transcripts encoding the gamma-subunit accumulate from the 8-cell stage mouse embryo to the blastocyst stage. The gamma-subunit protein is present surrounding the surfaces of all blastomeres of the early mouse embryo including the trophectoderm and inner cell mass of the blastocyst. In contrast to alpha 1- and beta 1-subunit proteins, which become confined to the basolateral region of the trophectoderm, the gamma-subunit protein retains an apolar distribution in the trophectoderm (148). Antisense oligonucleotide inhibition of the gamma-subunit during early murine development resulted in an inhibition of ouabain-sensitive $\mathrm{K}^{+}$transport and a delay in cavitation independent of an effect on $\mathrm{Na} / \mathrm{K}$-ATPase expression (148). These experiments indicate that this subunit certainly contributes to the events of blastocyst formation but perhaps in a manner independent of simply modulating $\mathrm{Na} / \mathrm{K}$-ATPase activity (148). Further research is required to fully define the interactions of the gamma-subunit with the alpha and beta subunits during early development (see figure 4).

\subsection{Isoform expression in the cow embryo}

The presence of multiple isoforms of the $\mathrm{Na} / \mathrm{K}$ ATPase during preimplantation development was first reported by Betts et al (71) from studies applied to the bovine early embryo. By application of RT-PCR methods, transcripts encoding alpha 1-, alpha 2-, alpha 3-, and beta 2 -isoforms of the $\mathrm{Na} / \mathrm{K}$-ATPase were detected throughout bovine pre-attachment development (71). Transcripts encoding the alpha 4-isoform were not detected in bovine embryos. As for the mouse embryo, this result was not unexpected as the expression of this $\mathrm{Na}^{+}$-pump isoform is reported to be confined to the testes (144). mRNAs encoding the beta 1-isoform were first detected at the bovine morula stage and also in blastocysts (71). Detection 


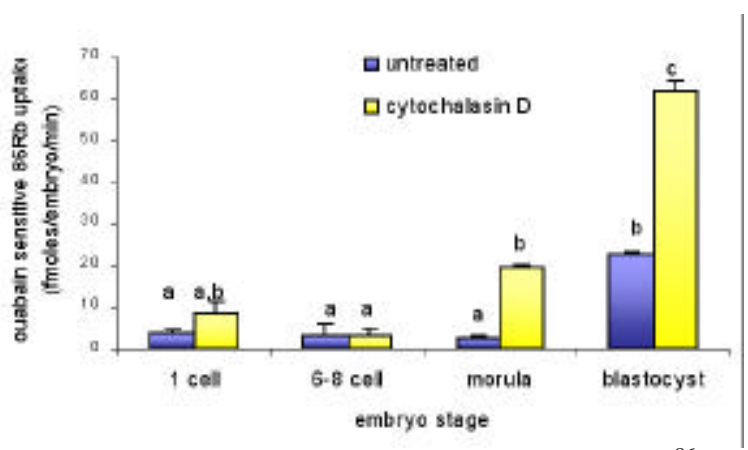

Figure 5. Pattern of detection of ouabain-sensitive ${ }^{86} \mathrm{Rb}^{+}$ transport in in vitro produced bovine embryos treated either with or without $5 \mathrm{ug} / \mathrm{ml}$ cytochalasin D. At the morula and blastocyst stages, tight junction formation between embryonic blastomeres is demonstrated by increased ${ }^{86} \mathrm{Rb}^{+}$ transport following disruption of cell-cell adhesion.

of beta 1-subunit mRNAs at the morula stage of bovine development agrees with the increase in the level of beta 1subunit mRNA (66), beta 1 subunit protein (178), and enzyme activity (61) observed during murine preimplantation development. The absence of beta 1subunit mRNAs in earlier bovine stages is distinct from that observed in the mouse and raises the possibility that other beta-subunit isoforms are responsible for the "house keeping" function of the enzyme in these stages. These results however, support the hypothesis that the timing of expression of the beta 1-subunit is closely coordinated with the onset of cavitation and may be important in regulating $\mathrm{Na} / \mathrm{K}$-ATPase activity and thus blastocyst formation. The beta 2-isoform is predominantly localized in the brain and nervous tissue. Its possible additional role in mediating cell adhesion (adhesion molecule of glia, AMOG) is of interest as it may provide a similar role during the first week of development $(156,184)$.

$\mathrm{Na} / \mathrm{K}$-ATPase isoform-specific antisera have been employed in whole mount indirect immunofluorescence assays to localize these polypeptides during bovine early development (55). Alpha 1-isoform polypeptides were localized to the basolateral cell margins of bovine trophectoderm and encircling each cell of the inner cell mass (ICM) (55). In contrast, alpha 3-isoform polypeptides were preferentially localized to apical cell surfaces of the trophectoderm and were not detected in the ICM (55). This is in contrast to studies applied to the mouse blastocyst, where alpha 3-isoform polypeptides were not localized to the trophectoderm cell margins in this species. Therefore, the localization of alpha 1-subunit polypeptides throughout bovine early development would agree with the findings for the murine early embryo. To date, alpha 3-subunit polypeptides have been primarily localized to neural tissue membranes (185). The localization of alpha 3-polypeptides to the apical trophectoderm surfaces in the bovine blastocyst was an unexpected finding. Therefore the possibility of both apical and basolateral $\mathrm{Na} / \mathrm{K}$-ATPase $\mathrm{Na}^{+}$-pumps exists for bovine trophectoderm. The results in total indicate that the role of the $\mathrm{Na} / \mathrm{K}$-ATPase in blastocyst formation is more complex than first thought. They have revealed species-specific differences including the presence of alpha 2-isoform transcripts throughout bovine early development and localization of alpha 3-subunit polypeptides to the apical domain of bovine trophectoderm cells (see figure 4). The specific contributions of each $\mathrm{Na} / \mathrm{K}$-ATPase subunit isoform to this blastocyst formation are not known but are the subject of present studies.

\subsection{Ouabain sensitivity and Enzyme activity}

Direct evidence supporting a role for $\mathrm{Na} / \mathrm{K}$ ATPase in blastocyst formation comes from ouabain studies (ouabain is a specific inhibitor of the enzyme) (63, 149, 157). Ouabain-sensitive primate cells, such as CV-1 African green monkey cells, are sensitive to $5 \times 10^{-8} \mathrm{M}$ ouabain, while ouabain-insensitive murine cells can survive treatment with ouabain at concentrations of $5 \times 10^{-4} \mathrm{M}$ $(186,187)$. Blastocyst expansion is restricted in the presence of ouabain and blastocyst re-expansion following cytochalasin-induced collapse is completely blocked in the presence of ouabain $(9,63,69,70)$. Dizio and Tasca (63) treated cytochalasin B-collapsed blastocysts with $10^{-3} \mathrm{M}$ ouabain, while Wiley (9) demonstrated an effect on cavitation when concentrations of at least $10^{-4}$ were used. Van Winkle and Campione (53) were unable to detect more than a two-fold increase in ouabain sensitive ${ }^{86} \mathrm{Rb}^{+}$uptake throughout murine preimplantation development when the increase in cell surface area between oocytes and blastocysts was considered. These results suggest that, although ouabain sensitive enzyme activity may not increase dramatically during murine preimplantation development, the presence of immunofluorescently detectable protein certainly does. Ouabain inhibition of $\mathrm{Na} / \mathrm{K}$-ATPase also promotes the exchange of intracellular $\mathrm{K}^{+}$for extracellular $\mathrm{Na}^{+}$in murine embryos demonstrating that $\mathrm{Na} / \mathrm{K}$-ATPase activity maintains steep $\mathrm{Na}^{+}$and $\mathrm{K}^{+}$ gradients in embryonic cells just as it does for other cells (47). We have demonstrated that bovine blastocysts are more sensitive to ouabain than murine blastocysts (71). We measured ouabain-sensitive ${ }^{86} \mathrm{Rb}^{+}$transport and therefore $\mathrm{Na}^{+}$-pump activity throughout bovine pre-attachment development in cytochalasin D treated embryos (55; see figure 5). Cytochalasin treatment is employed to disrupt trophectoderm tight junctions to allow ouabain access to $\mathrm{Na}^{+}$-pumps localized to the basolateral membranes of the trophectoderm (71). ${ }^{86} \mathrm{Rb}^{+}$uptake was largely maintained at a constant level from the 1-cell zygote to the 6-8 cell stage, but then increased dramatically to the bovine blastocyst stage. Increased ouabain-sensitive ${ }^{86} \mathrm{Rb}^{+}$uptake parallels the increased abundance of $\mathrm{Na} / \mathrm{K}$-ATPase subunit mRNAs, subunit proteins, and enzyme activity observed during murine and bovine blastocyst formation. In contrast to the two-fold increase in ouabain-sensitive ${ }^{86} \mathrm{Rb}^{+}$uptake reported for murine embryos throughout the first week of development (53), we observed over a 18 -fold increase in uptake from the 6-8 cell to bovine blastocyst stages (cytochalasin treated groups) (55). In addition, in contrast to findings in the murine blastocyst considerable ouabainsensitive ${ }^{86} \mathrm{Rb}^{+}$uptake was measured in bovine blastocysts not subjected to cytochalasin treatment (55). Van Winkle and Campione (53) also reported ${ }^{86} \mathrm{Rb}^{+}$transport within intact murine blastocysts raising the possibility that a component of this $\mathrm{Na} / \mathrm{K}$-ATPase transport activity may be 
directed from the apical trophectoderm membrane of mammalian blastocysts. Alternatively, the junctions between trophectoderm cells might be leaky, allowing the paracellular movement of ${ }^{86} \mathrm{Rb}^{+}$and ouabain into the blastocyst cavity.

\subsection{Role of $\mathrm{Na} / \mathrm{K}$-ATPase in Cavitation}

Incubation of mouse embryos with antiserum raised against E-cadherin prevents normal cavitation (67). Treated embryos contained a variable number of intrablastomeric fluid-filled cavities, which were encircled with $\mathrm{Na} / \mathrm{K}$-ATPase immunofluorescence (67). Under these treatment conditions the trophectoderm apical junctional complex was disrupted and embryos were observed in which (those without extensive fluid-filled cavities) the cytoplasm of some blastomeres became densely packed with smaller vesicles, which were possibly the origin of the larger fluid-filled cavities (67). These results suggest that the targeting of the nascent Na-pumps to the appropriate trophectoderm cell membranes was impaired thus confining the $\mathrm{Na} / \mathrm{K}$-ATPase within cytoplasmic secretory vesicles. This, combined with activity of the enzyme, may result in the osmotic accumulation of water in the vesicles to form intracellular fluid-filled cavities $(52,67)$. A similar effect occurs when embryos are cultured in medium with minimal calcium (78). Geering et al. (188) suggested that the nascent catalytic subunit of $\mathrm{Na} / \mathrm{K}$-ATPase aligns with the beta-subunit within the membranes of the rough endoplasmic reticulum (RER) and golgi en route to the plasma membrane. The nascent enzyme could undergo cation-dependent conformational changes under these conditions (188, 189). Normally, (as observed by the immunoreactivity in untreated morulae), the nascent enzyme would not begin to transport $\mathrm{Na}^{+}$and $\mathrm{K}^{+}$prior to its insertion into the plasma membrane. These findings certainly linked the normal targeting and insertion of the $\mathrm{Na} / \mathrm{K}$-ATPase to the trophectoderm basolateral cell margins with normal blastocyst formation.

The relative insensitivity of mouse cavitation to ouabain (sensitive to $10^{-3} \mathrm{M}$ ouabain) implies that the more ouabain sensitive alpha 2- and alpha 3-isoforms are not likely the predominant isoforms. In contrast to mouse embryos, bovine embryos are extremely sensitive to ouabain $\left(10^{-7}-10^{-9} \mathrm{M}\right)$ raising the possibility that the alpha 1 -isoform is not the predominant alpha-subunit in early embryos of this species. The immunofluorescence localization of the alpha 3-subunit to the apical trophectoderm membrane domains in bovine blastocysts may in part, explain their greater ouabain sensitivity when compared to their murine counterparts. In addition, bovine blastocysts can be collapsed simply by treatment with high $\left(10^{-6} \mathrm{M}\right.$ to $\left.10^{-3} \mathrm{M}\right)$ ouabain, without the initial treatment with cytochalasin D (55). These data support the possibility that the apical alpha 3-subunit plays an active role in blastocyst formation in the bovine embryo.

The detection of multiple subunit isoforms, and varying species sensitivities to ouabain, raise questions such as: What roles do various isozymes of the sodium pump have during early development? Do the varying ouabain sensitivities displayed by these species reflect comparative variations in the abundance of alpha-isoforms? Different isoforms display distinct ouabain sensitivities and ion affinities, and $\mathrm{Na}^{+}$and $\mathrm{K}^{+}$concentrations can influence isoform expression. Jewell and Lingrel (169) found that rat alpha 1- and alpha 2-isoforms in HeLa cells have similar apparent affinities for $\mathrm{Na}^{+}$, but that the alpha 3-isoform has a 4-fold lower affinity for this ion. Low $\mathrm{K}^{+}$concentrations decrease alpha 2-subunit mRNA levels and protein levels by $38 \%$ and $82 \%$, respectively, in hypokalemic skeletal muscle (190). Although vectorial transport of $\mathrm{Na} / \mathrm{K}$ ATPase to the basolateral surface of membranes is conventional (191) apical localization of the sodium pump is reported for several tissues (192, 193). Immunofluorescence studies do not shed any light on the functional significance of alpha 1- and alpha 3-subunit polypeptides to the overall mechanism of cavitation, although treatment of collapsed bovine blastocysts with $10^{-}$ ${ }^{9} \mathrm{M}$ ouabain causing reduced blastocyst re-expansion is highly suggestive of the alpha 3-isoform contributing to blastocyst formation (71). We hypothesize that an apical trophectoderm alpha 3-isoform could participate in regulating the steepness of the trans-trophectoderm $\mathrm{Na}^{+}$ gradient required to drive the osmotic accumulation of water across this epithelium to form the blastocyst cavity. Support for this role comes from studies that report the alpha 3-isoform may regulate high intracellular $\mathrm{Na}^{+}$loads in order to restore physiological $\mathrm{Na}^{+}$levels (194). We are uncertain as to how high trophectoderm cell intracellular $\mathrm{Na}^{+}$levels rise during blastocyst formation. Baltz et al., (47) measured intracellular $\mathrm{Na}^{+}$and $\mathrm{K}^{+}$levels up to the murine morulae stage. We propose that the hypothesized increase in intracellular $\mathrm{Na}^{+}$, required to drive blastocyst formation, must be regulated. An apical alpha 3-isozyme of the $\mathrm{Na} / \mathrm{K}$-ATPase could perform this role and maintain the trophectoderm cell $\mathrm{Na}^{+}$gradient within physiological limits. Since the alpha 3-subunit displays a much lower affinity for cytoplasmic $\mathrm{Na}^{+}$than the alpha 1-subunit (175), the presence of an apical alpha 3-subunit would not necessarily disrupt a trans-trophectoderm $\mathrm{Na}^{+}$gradient (driven by the basolateral $\mathrm{Na} / \mathrm{K}$-ATPase), but instead could serve to modulate the gradient by moving $\mathrm{Na}^{+}$from inside the cell to the extra-embryonic environment. Functional studies applied to isoform specific null mutants are required to determine the precise ion transport properties of each $\mathrm{Na} / \mathrm{K}$-ATPase isoform during blastocyst formation.

We have initiated studies employing antisense oligonucleotide inhibition of $\mathrm{Na} / \mathrm{K}$-ATPase isoform expression during bovine early development. Bovine zygotes have been cultured with alpha 1-isoform specific antisense phosphorothioate oligodeoxynucleotides (ODNs) to disrupt translation of this protein. Preliminary results have demonstrated that treatment of bovine 6-8 cell embryos with alpha 1-antisense ODNs significantly impairs blastocyst formation (see figure 6). It has however been very difficult to standardize this effect of alpha 1-isoform ODNs on blastocyst formation. Therefore examining the consequences to early development following the targeted deletion of $\mathrm{Na} / \mathrm{K}$-ATPase subunit isoforms represents a more viable route for discerning the specific contributions of each isoform to blastocyst formation. 
A

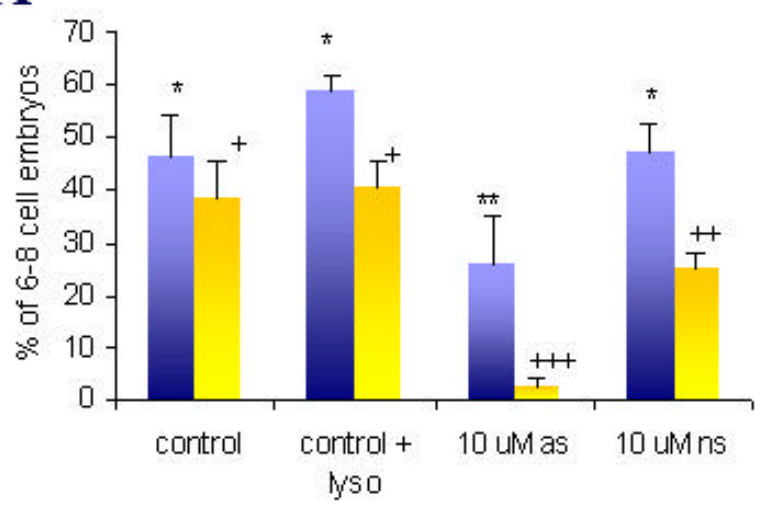

treatment
B

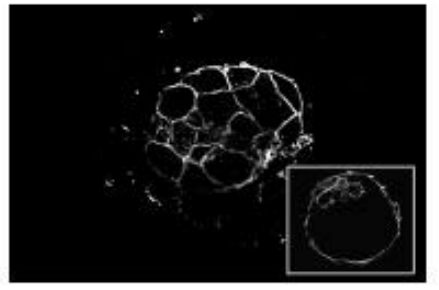

d8 blastocyst

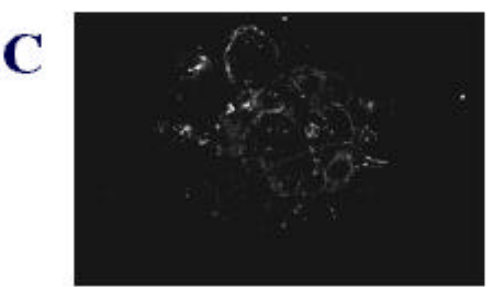

Figure 6. Development of bovine embryos treated with $10 \mathrm{u}$ M alpha 1-subunit antisense oligonucleotides in vitro (A). Antisense treatment significantly reduced development to the blastocyst stage $(n=5$ replicates of 20 embryos; $p<0.05)$. When alpha 1 subunit protein expression was compared to control embryos (B), alpha 1 antisense treated embryos demonstrated a marked reduction in immunofluorescence signal (C).

\subsection{Murine Knock-outs}

Several studies have reported outcomes from gene targeting experiments that have "knocked-out" the expression of specific $\mathrm{Na} / \mathrm{K}$-ATPase subunit isoforms. Studies from Dr. Jerry Lingrel's laboratory (University of Cincinnati) have demonstrated that alpha 1 subunit null mutants are never born and must suffer a developmental lethality (the precise time of their demise is unknown), while alpha 2-subunit null mutants are born but do not survive the first day (195). Alpha 2-isoform null mutants have also been generated by homologous recombination and these mice suffer no ill effects until after birth (154). Other isoforms have not been targeted as yet but the findings would suggest that the alphal-subunit is the predominant isoform required for development while the beta 1-isoform is the most reasonable candidate for regulating the expression of functional enzyme units in the trophectoderm. Experiments examining the timing of lethality for the alpha 1-subunit null mutants are currently underway and it is expected that this murine line will prove useful for defining the role of the alpha 1-isoform during blastocyst formation.

\section{WATER TRANSPORT AND BLASTOCYST FORMATION}

Transporting epithelia are characterized by the rapid passage of water across the cell layer (196-199). However, the mechanisms that facilitate the movement of water across the trophectoderm are largely unexplored. The processes that regulate the uptake and release of water by living cells are fundamental to cell viability. Water can diffuse through lipid bilayers, and all cell membranes display some level of permeability to water (for review see $(196,197,200,201))$. The diffusional permeability $\left(\mathrm{P}_{\mathrm{d}}\right)$ of cell membranes varies but is usually small ie. $<1 \mathrm{~m} \mathrm{~min}^{-1}$ $\mathrm{atm}^{-1}(196,198,202)$. Although this value is low, it is sufficient for most cell types to regulate their volumes. Thus, it was widely believed that simple diffusion was the primary if not exclusive mechanism for mediating water movement through biological membranes and that water channels were not necessary (201). Water flow in some cell types such as red blood cells is, however, much greater than that predicted by simple diffusion alone (203). This has resulted in the hypothesis that cell membranes possess channels that facilitate water flow (196-199). Evidence supporting the presence of "water channels" has come from biophysical studies of red blood cells, kidney collecting ducts and toad bladder epithelial cells (200. 204-207; see figure 7). Water permeabilities across these membranes are 10- to 100-fold greater than that observed in phospholipid bilayers. The ratio of osmotic permeabilities $\left(\mathrm{P}_{\mathrm{f}}\right.$, determined by the measurement of bulk water flow in response to an osmotic gradient) to diffusive permeabilities $\left(\mathrm{P}_{\mathrm{d}}\right.$, measurement of the flux of isotopic water under conditions of equal osmolality) are far greater than 1 (ratio observed in lipid bilayers) (196-213). This increased ratio is characteristic of water channel-mediated fluid transport. Extensive research conducted largely over the past ten years has indicated that plasma membranes display a varied permeability to water movement and that in cases of rapid and large volume water movement specific water transport molecules must exist (for review see (196, 197, 200, 201). These types of studies have resulted in the characterization of a family of 10 molecular water channels or Aquaporins. We hypothesize that AQP water channels are present in the trophectoderm cells of the preimplantation embryo and that they function as conduits for the trans-trophectodermal fluid movements associated with blastocyst formation.

\subsection{Aquaporins}

Aquaporins (AQPs) belong to a family of major intrinsic membrane (MIP) proteins, and function as molecular water channels that allow water to flow rapidly across plasma membranes in the direction of osmotic gradients (see figure 8). Ten different AQPs have been identified in mammals $(197,205-207,209,214)$.

AQP 0/MIP28 was isolated from lens epithelium (215). Absence of normal AQP 0 protein is linked to 

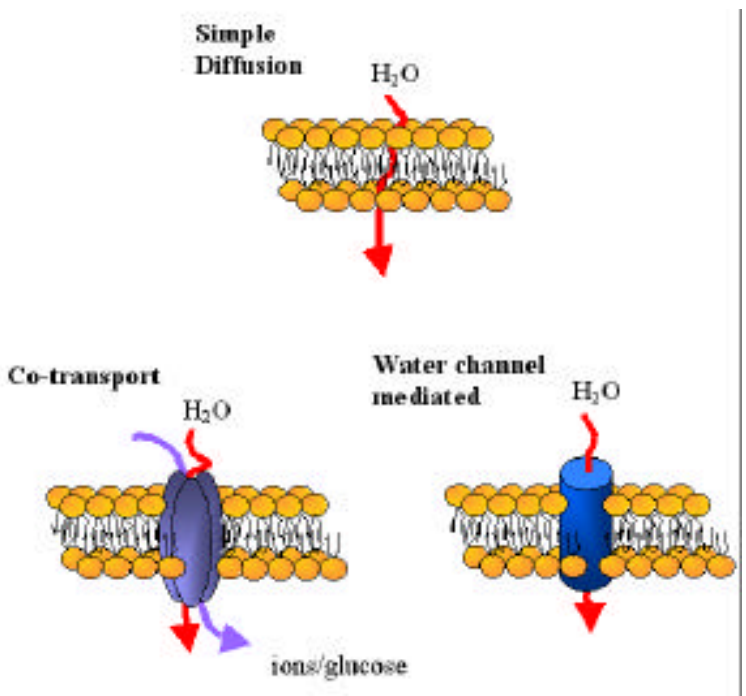

Figure 7. Mechanisms of water movement across biological membranes. Water generally crosses the lipid bilayers by i) simple diffusion, ii) co-transport during the transport cycle of enzymes and other transporters or iii) through pores created by the expression of aquaporins.

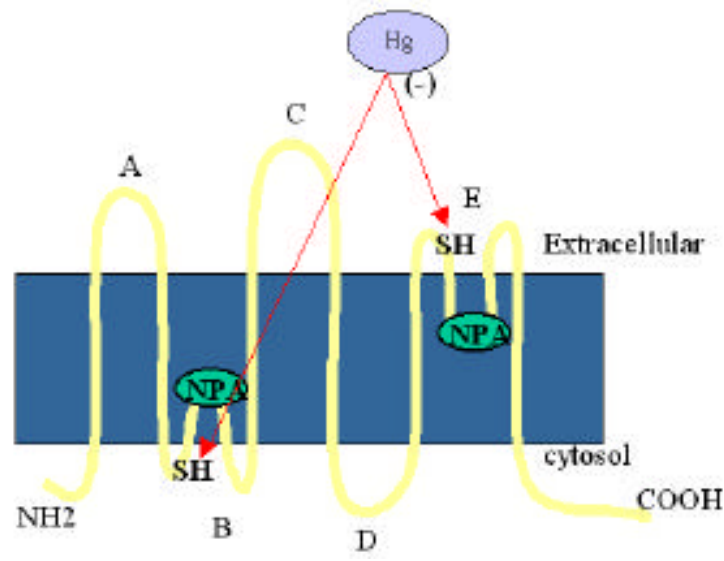

Figure 8. Theoretical membrane structure aquaporin proteins. AQP proteins consist of 6 membrane spanning domains and 5 loop domains, of which infoldings of loops $\mathrm{B}$ and $\mathrm{E}$ are believed to form the water pore and possess SH-groups which when bound by mercury result in inhibition of aquaporin function.

cataract formation in mutant mice (215). AQP 1/channel forming integral membrane protein (CHIP)-28 is the most ubiquitous of the AQP family and is expressed in a number of organs and tissues (216-219). AQP 1 is the major water channel in red blood cells and in the brain it is only found in the choroid plexus (216-219). AQP 2 is the vasopressin responsive water channel found in kidney collecting ducts (220-222). This water channel is stored in cytoplasmic vesicles that fuse with the apical membrane following exposure to vasopressin (221). Loss-of-function mutations in this gene result in nephrogenic diabetes insipidus (223). AQP 3 permits the passage of water, glycerol and urea and is generally located to the basolateral membrane of epithelial cells (222-225). AQP 4 is a mercury insensitive water channel also generally localized to the basolateral membranes of a variety of epithelial cells (226-231). AQP 5 is localized to apical membranes, and is involved in the secretion of saliva, tears and pulmonary fluid $(232,233)$. Murine null mutants for AQP 5 display a marked reduction in saliva production (233). AQP 6 has a low water conducting ability and its expression may be confined to the kidney (234). AQP 7 permits the passage of both water and glycerol and is expressed in a transient fashion in late spermatids and maturing sperm and weakly in kidney and heart (235). AQP 8 is also localized in the testes as well as placenta, colon, liver, and heart (236). AQP 9 is the most recently cloned water channel and is most similar to AQP 3 and 7 in that it also permits glycerol transport. It is expressed in leukocytes and liver and is weakly expressed in the heart, kidney and small intestine $(224,237,238)$. The blastocyst provides a comparatively simple system from which fundamental information on AQP gene expression and function can be obtained.

\subsection{Aquaporin Expression and Function During Blastocyst Formation}

Two studies have examined the presence of aquaporin (AQP) family transcripts during murine preimplantation development. The first by Edashige et al., (239) reported the detection of mRNAs encoding AQPs 3, 7,8 and 9 in preimplantation stages. mRNAs encoding AQPs $1,2,4,5$, and 6 were not detected in any stage. Interestingly mRNAs encoding AQPs 8 and 9 were only detected in blastocysts. Offenberg et al., (240) conducted a similar study but reported that mRNAs encoding AQPs 1 , $3,5,6,7$, and 9 were detectable in all stages from 1-cell zygotes to the blastocyst stage. In addition, AQP 8 mRNAs were detected only in morula and blastocyst stages. Although Offenberg et al., (240) did not employ a semiquantitative analysis it was noted that for two additional AQPs (AQP 3 and 7) there was a consistent increase in signal in morula and blastocyst stage embryos suggesting that mRNAs encoding AQPs 3, 7, and 8 may be upregulated in conjunction with blastocyst formation. Confirmation of this possibility however must be made by applying semi-quantitative methods of analysis. The findings from these two studies vary somewhat. The differences observed between these two studies may be related to primer design or amplification efficiency differences or perhaps to differences in starting total mRNA levels or size of embryo batches employed. Never the less these studies do agree that the mRNAs encoding several AQPs are expressed during preimplantation development and that for at least one AQP (AQP8) expression is coincident with blastocyst formation.

We have also examined the expression of mRNAs encoding AQPs during bovine early development and found that mRNAs encoding AQP 3, 5, 8 and 9 are detectable in bovine blastocysts and control tissues. The absence of bovine AQP sequence data in the GenBank has hampered the design of effective primer sets for this species and may account for the difference in AQP family member expression between mouse and bovine embryos. These results indicate that several AQP gene products are expressed during murine and bovine blastocyst formation. 


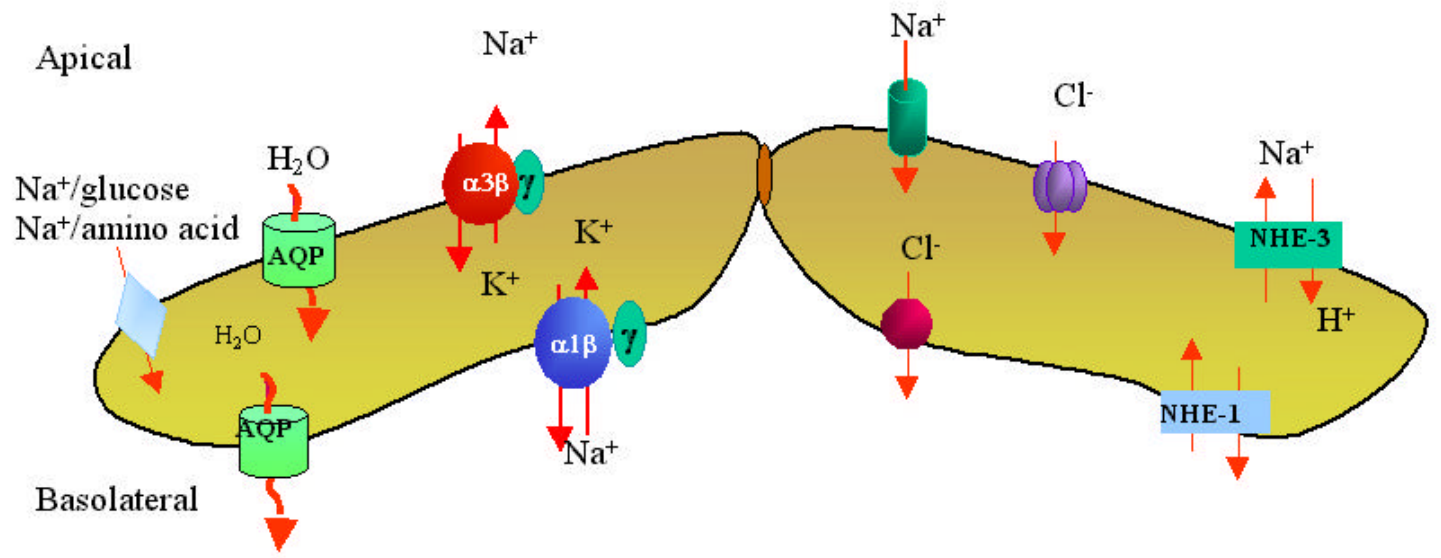

Figure 9. Model of ion and fluid transport across the trophectoderm of the mammalian blastocyst.

We have also initiated experiments to contrast the distribution of $\mathrm{AQP}$ polypeptides throughout murine early development by confocal immunofluorescence microscopy. Preliminary results indicate that AQP 3, 6, 8, and 9 polypeptides are present in murine blastocysts with AQP 3 polypeptides localized to trophectoderm basolateral domains, AQP 8 and 9 polypeptides display an apical and basolateral localization pattern and AQP 6 polypeptides display a cytoplasmic localization. Preliminary results assessing sensitivity of blastocyst expansion to treatment with inhibitors following exposure to hypo-osmotic medium also indicate a role for AQP water channels in blastocyst formation.

Future experiments will investigate the functional roles of these AQPs to blastocyst formation and will localize each expressed AQP during early development as effective antisera for each AQP become available. The pursuit of functional data is hampered by the absence of specific AQP inhibitors. The existence of AQP null mutant murine lines and the application of antisense oligodeoxynucleotide approaches should enable the pursuit of the individual and collective roles that AQPs play during early development. We expect that much more information regarding the role of AQPs in regulating blastocyst formation will emerge over the next few years.

\section{7 . SUMMARY AND FUTURE PROSPECTS}

There is a great need to understand the mechanisms controlling mammalian preimplantation development in order to develop rational interventions to either promote or inhibit fertility $(3,5,241,242)$. Current research is addressing this need and is aimed at providing an eventual understanding of the causative events underlying early embryo loss and in ensuring that assisted reproductive technologies are applied in a safe and efficient way. The results from these studies impact on our understanding of basic transport biology and physiology, epithelial (trophectoderm) cell differentiation and blastocyst formation and thus improve our ability to understand human infertility, early embryo loss and epithelial cell disease states.
Blastocyst formation is dependent upon the expression of several gene products including $\mathrm{Na} / \mathrm{K}$ ATPase subunits, E-cadherin, and tight junction components (see figure 9). This morphogenetic event is initiated during compaction as stable E-cadherin/catenin cell-to-cell adhesion junctions form as a prelude to focal tight junction formation. Trophectoderm differentiation proceeds as tight junctions mature and assist in the establishment of distinct apical and basolateral cell membrane domains. By the late morula stage, the beta 1 subunit of the $\mathrm{Na} / \mathrm{K}$-ATPase is upregulated and this occurs in conjunction with the polarized localization of alpha 1 isoforms to the basolateral domains of the outer trophectoderm, at the onset of fluid accumulation. In the bovine embryo, a second alpha 3 -isoform is expressed and assumes a predominantly apical localization pattern. It is hypothesized that the blastocyst cavity formation is facilitated by a trans-trophectoderm ion gradient established, in part, by a polarized trophectoderm $\mathrm{Na} / \mathrm{K}$ ATPase, which facilitates the osmotic movement of water into the extracellular space to form the fluid-filled cavity of the blastocyst. The apical alpha 3 isoform in the bovine trophectoderm may assist in regulating the steepness of the $\mathrm{Na}^{+}$gradient across the epithelium. Blastocyst expansion only occurs when the tight junction permeability seal fully forms to restrict the leakage of fluid via paracellular routes, ensuring the expansion of the cavity as fluid accumulates. The mammalian blastocyst also expresses mRNAs encoding several AQPs. These water channels may direct the rapid movement of water across the epithelium to form the blastocyst fluid. The precise roles of $\mathrm{Na} / \mathrm{K}$-ATPase isoforms and AQP water channels during blastocyst formation have not been defined. Future research will be directed at defining their individual and collective roles in supporting blastocyst formation.

\section{ACKNOWLEDGMENTS}

The authors wish to thank Drs. Mark Westhusin, Dean Betts, Quinton Winger, Hanne Offenberg, Jerry Kidder, Daniel MacPhee, Holly Jones and Mr. David Natale, Mr. J. Looye and Mrs. Anita Caveney for their contributions to studies cited from the authors laboratory 
related to this topic. Work referred to from the authors laboratory was supported by grants from the Medical Research Council (MRC), National Sciences and Engineering Research Council (NSERC) of Canada to AJW and the National Cooperative Program on Nonhuman

\section{REFERENCES}

1. Edmonds D,K, K.S. Lindsay, J.F. Miller, E. Williamson, \& P.J. Wood: Early embryonic mortality in woman. Fert Steril 38, 447-453 (1982)

2. Edwards R.G: Recent scientific and medical advances in assisted human conception. Inter J Dev Biol 41, 255-262 (1997)

3. ISLET Working group: Elster A.L, R. Gatter, T.F. Horwich, A. Jaeger, S. Klock, E. Pergament, F. Pizzulli, R. Shaoiro, M. Siegler, P. Smith , \& S. Zager: ART into science: regulation of fertility techniques. Science 28,1651652 (1998)

4. McLaren A: The embryo. In: Reproduction in Mammals: Embryonic and Fetal Development. Eds: Austin C.R. Short R.V, Cambridge University Press, Cambridge pp. 1-26 (1982)

5. Seamark R.F, \& J.S. Robinson: Potential health problems stemming from assisted reproduction programs. Hum Reprod 10, 1321-1329 (1995)

6. Watson A.J: The cell biology of blastocyst development. Mol Reprod Dev 33,492-504 (1992)

7. Wiley L.M, G.M. Kidder, \& A.J. Watson: Cell polarity and development of the first epithelium. BioEssays 12, 6773 (1990)

8. Wiley L: Development of the blastocyst: role of cell polarity in cavitation and cell differentiation. In The Mammalian Preimplantation Embryo: Regulation of Growth and Differentiation In vitro. Ed: Bavister, B, Plenum Publishing Company, New York, NY. 65-93 (1987)

9. Wiley L.M: Cavitation in the mouse preimplantation embryo: $\mathrm{Na} / \mathrm{K}$-ATPase and the origin of the nascent blastocoelic fluid. Dev Biol 105, 330-342 (1984)

10. Wiley L.M: Trophectoderm: the first epithelium to develop in the mammalian embryo. Scan Microsc 2,417426 (1988)

11. Watson A.J, M.E. Westhusin, P.A. De Sousa, D.H. Betts, \& L.C. Barcroft: Gene expression regulating blastocyst formation. Theriogenology 51, 117-133 (1999)

12. Biggers J.D, J.E. Bell, \& D.J. Benos: Mammalian Blastocyst: transport functions in a developing epithelium. Am. J. Physiol 255,C419-C432 1988. in vitro Fertilization and Preimplantation Development by NIH Cooperative Agreement U01HD34580. LCB is the recipient of an NSERC Post Graduate Scholarship and AJW is a recipient of a Premier's Research Excellence Award.

13. Lewis W.H, \& E.S. Wright: On the early development of the mouse. Contrib Embryol Carneg Inst 25,114-143 (1935)

14. Ducibella T, \& E. Anderson: Cell shape and membrane changes in the eight-cell mouse embryo: prerequisites for morphogenesis of the blastocyst. Dev Biol 47, 45-58 (1975)

15. Ziomek C.A, \& M.H. Johnson: Cell surface interaction induces polarization of mouse 8-cell blastomeres at compaction. Cell 21, 935-942 (1980)

16. Ziomek C.A, H.P.M. Pratt, \& M.H. Johnson: The origins of cell diversity in the early mouse embryo. In. Functional Integration of Cell in Animal Tissues: British Society for Cell Biology Symposium 5 Eds: Pitts J.D, Finbow M.E, Cambridge University Press, London. pp. 149-165 1982.

17. Ziomek C.A: Cell polarity in the preimplantation mouse embryo. In: The Mammalian Preimplantation Embryo: Regulation of Growth and Differentiation In vitro. Ed; Bavister BD, Plenum Publishing. New York. Pp 23-41 (1987)

18. Pratt H.P.M, C.A. Ziomek, W.J.D. Reeve, \& M.H. Johnson: Compaction of the mouse embryo: an analysis of its components. J Embryol exp Morphol 70, 113-132 (1982)

19. Schultz R.M: Regulation of zygotic gene activation in the mouse. BioEssays 15, 531-538 (1993)

20. Clegg K.B, \& L. Piko: Quantitative aspects of RNA synthesis and polyadenylation in 1-cell and 2-cell mouse embryos. J. Embryol. exp. Morph 74, 169-182 (1983)

21. Clegg K.B, \& L. Piko: Poly(A) length, cytoplasmic adenylation, and synthesis of poly(A)+RNA in mouse embryos. Dev Biol 95,331-341 (1983)

22. DeSousa P.A, A.J. Watson, G.A. Schultz, \& S. Bilodeau-Goeseels: Oogenetic and zygotic gene expression directing early bovine embryogenesis. Mol Reprod Dev 51, 112-121(1998)

23. Giebelhaus D.H, J.J. Heikkila, \& G.A. Schultz: Changes in the quantity of histone and actin mRNA during the development of preimplantation mouse embryos. Dev Biol 98, 148-154 (1983)

24. Giebelhaus D.H, H.M. Weitlauf \& G.A. Schultz: Actin mRNA content in normal and delayed implanting mouse embryos. Dev Biol 107, 407-413 (1985)

25. Graves R.A, W.F. Marzluff, D.H. Giebelhaus, \& G.A. Schultz, G.A: Quantitative and qualitative changes in 
histone gene expression during early mouse embryo development. Proc Natl Acad Sci USA 82, 5685-5689 (1985)

26. Kidder G.M, \& J.R. McLachlin: Timing of transcription and protein synthesis in preimplantation mouse embryos. $J$ Embryol exp Morphol 89, 223-234 (1985)

27. Latham K.E, J.J. Garrels, C. Chang, \& D. Solter: Quantitative analysis of protein synthesis in mouse embryos. I. extensive reprogramming at the one-and twocell stages. Development 112, 921-932 1991.

28. Piko L, \& K.B. Clegg: Quantitative changes in total RNA, total poly(A), and ribosomes in early mouse embryos. Dev Biol 98,362-378 (1982)

29. Ram P.T, \& R.M. Schultz,: Reporter gene expression in G2 of the 1-cell mouse embryo. Dev Biol 156,552-556 (1993)

30. Telford N.A, A.J. Watson, \& G.A. Schultz: Transition from maternal to embryonic control in early mammalian development: a comparison of several species. Mol Reprod Dev 26, 90-100 (1990)

31. Kidder G.M, \& A.J. Watson: Gene expression required for blastocoel formation in the mouse. In: Early Embryo Development and Paracrine Relationships UCLA Symposium on Molecular and Cellular Biology, New Series Vol 117. Eds: Heyner S, Wiley LM. Wiley-Liss Publishers New York. Pp 97-107 (1990)

32. Kidder G.M: Genetic information in the preimplantation embryo. In: Meiosis II. Contemporary Approaches to the Study of Meiosis. Eds: Haseltine F.P, Heyner S, AAAS Press, Washington DC. pp. 187-199 (1993)

33. Kidder G.M: Genes involved in cleavage, compaction, and blastocyst formation. In. Genes in Mammalian Reproduction. Ed: Gwatkin, R.B.L, J. Wiley and Sons. New York. pp 45-71 (1992)

34. Schultz G.A, W. Dean, A. Hahnel, N. Telford, D. Rappolee, Z. Werb, \& R. Pedersen: Changes in RNA and protein synthesis during development of the preimplantation mouse embryos. In: UCLA Symposia on Molecular and Cellular Biology, New Series: Early Embryo Development and Paracrine Relationships, Vol 117. Eds: Heyner S, Wiley L, Wiley-Liss Publishing. New York. pp 27-46 (1990)

35. Schultz G.A: Utilization of genetic information in the preimplantation mouse embryo. In: Experimental Approaches to Mammalian Preimplantation Development. Eds: Rossant J, Pedersen RA, Cambridge University Press, New York. pp 239-266 (1986)

36. Taylor K.D, \& L. Piko: Patterns of mRNA prevalence and expression of B1 and B2 transcripts in early mouse embryos. Development 101, 877-892 (1987)
37. Garrels J.L: The QUEST system for quantitative analysis of two-dimensional gels. J Biol Chem 264, 52695282 (1989)

38. Viuff D, B. Avery, T. Greve, W.A. King, \& P. Hyttel: Transcriptional activity in in vitro produced bovine twoand four-cell embryos. Mol Reprod Dev 43,171-179 (1996)

39. Plante L, C. Plante, D.L. Shepard, \& W.A. King: Cleavage and $3 \mathrm{H}$-uridine incorporation in bovine embryos of high in vitro developmental potential. Mol Reprod Dev 39, 375-383 (1994)

40. Memili E, \& N.L. First: Developmental changes in RNA polymerase II in bovine oocytes, early embryos and effect of alpha amanitin on early development. Mol Reprod Dev 51, 381-389 (1998)

41. Memili E, T. Dominko, \& N.L. First,: Onset of transcription in bovine oocytes and preimplantation embryos. Mol Reprod Dev 51, 36-41(1998)

42. Natale D.R, G.M. Kidder, M.E. Westhusin, \& A.J. Watson: Assessment by differential display-RT-PCR of mRNA transcript transitions and alpha-amanitin sensitivity during bovine preattachment development. Mol Reprod Dev 55,152-163 (2000)

43. Barnes F.L, \& N.L First: Embryonic transcription in in vitro cultured bovine embryos. Mol Reprod Dev 29, 117 $123(1991)$

44. Braude P.R: Control of protein synthesis during blastocyst formation in the mouse. Dev Biol 68, 440-452 (1979)

45. Benos D.J, \& R.S. Balaban: Current topic: Transport mechanisms in preimplantation mammalian embryos. Placenta 11, 373-380 (1990)

46. Borland R.M: Transport processes in the mammalian blastocyst. In: Development in Mammals. Eds: Johnson M, North Holland Publishing Co. New York, pp 31-68 (1977)

47. Baltz J.M, S.S. Smith, J.D. Biggers, \& C. Lechene: Intracellular ion concentrations and their maintenance by $\mathrm{Na} / \mathrm{K}-\mathrm{ATPase}$ in preimplantation embryos. Zygote 5,1-9 (1997)

48. Baltz J.M: Intracellular $\mathrm{pH}$ regulation in the early embryo. BioEssays 15, 523-530 (1993)

49. Powers R.D, \& J.T. Tupper: Ion transport and permeability in the mouse egg. Exp Cell Res 91, 413-421 (1975)

50. Powers R.D, \& J.T. Tupper: Developmental changes in membrane transport and permeability in the early mouse embryo. Dev Biol 56, 306-315 (1977) 
51. Borland R.M, J.D. Biggers, \& C.P. LeChene: Studies on the composition and formation of the mouse blastocoele fluid using electron probe microanalysis. Dev Biol 68, 440452 (1977)

52. Manejwala F.M, E.J. Cragoe Jr, \& R.M. Schultz: Blastocoel expansion in the preimplantation mouse embryo: role of extracellular sodium and chloride and possible routes of their entry. Dev Biol 133, 210-220 (1989)

53. Van Winkle L.J, \& A.L. Campione: Ouabain-sensitive $\mathrm{Rb}+$ uptake in mouse eggs and preimplantation conceptuses. Dev Biol 146, 158-66 (1991)

54. Van Winkle L.J, N. Haghighat, A.L. Campione, \& J.M. Gorman: Glycine transport in mouse eggs and preimplantation conceptuses. Biochem Biophys Acta 941, 241-256 (1988)

55. Betts D.H, L.C. Barcroft, \& A.J. Watson: Na/KATPase-mediated 86RB+ uptake and asymmetrical trophectoderm localization of alpha 1 and alpha $3 \mathrm{Na} / \mathrm{K}$ ATPase isoforms during bovine preattachment development. Dev Biol 197, 77-92 (1998)

56. Borland R.M, \& R.J. Tasca: Activation of a Na+dependent amino acid transport system in preimplantation mouse embryos. Dev Biol 30, 169-182 (1974)

57. Miller J.G.O, \& G.A. Schultz: Amino acid transport in mouse blastocyst compartments. J Embryol exp Morphol 89,149-158 (1985)

58. Hobbs J.G, \& P.L. Kaye: Glycine and Na+ transport in preimplantation mouse embryos. J Reprod Fertil 77, 61-66 (1986)

59. Wiley L.M, J.E. Lever, C. Pape, \& G.M. Kidder: Antibodies to renal $\mathrm{Na}$ /glucose co-transport system localize to the apical plasma membrane domain of polar mouse embryo blastomeres. Dev Biol 143, 149-161 (1991)

60. Zhao Y, P.A. Doroshenko, S.L. Alper, J.M. Baltz: Routes of $\mathrm{Cl}$ - transport across the trophectoderm of the mouse blastocyst. Dev Biol 189, 148-160 (1997)

61. Vorbrodt A, M. Konwinski, D. Solter, \& H. Koprowski, $\mathrm{H}$ : Ultrastructural cytochemistry of membrane-bound phosphatases in preimplantation mouse embryos. Dev Biol 124, 451-456 (1977)

62. Watson A.J, \& G.M. Kidder: Immunofluorescence assessment of the timing of appearance and cellular distribution of $\mathrm{Na} / \mathrm{K}$-ATPase during mouse embryo genesis. Dev Biol 126, 80-90 (1988)

63. Dizio S.M, \& R.J. Tasca: Sodium-dependent amino acid transport in preimplantation mouse embryos III: $\mathrm{Na} / \mathrm{K}$ ATPase linked mechanism in blastocysts. Dev Biol 59,198205 (1977)
64. Manejwala F.M, E. Kaji, \& R.M. Schultz: Development of activatable adenylate cyclase in the preimplantation mouse embryo and a role for cAMP in blastocoel formation. Cell 46, 95-103 (1986)

65. Gardiner C.S, M.A. Grobner, \& A.R. Menino Jr: Sodium/Potassium adenosine triphosphatase alpha-subunit mRNA levels in early rabbit embryos. Biol Reprod 42, 539544 (1990)

66. Watson A.J, C. Pape, J.R. Emanuel, R. Levenson, \& G.M. Kidder: Expression of Na/K-ATPase alpha and beta subunit genes during preimplantation development of the mouse. Dev Genet 11, 41-48 (1990)

67. Watson A.J, C.H. Damsky, \& G.M. Kidder: Differentiation of an epithelium: factors affecting the polarized distribution of $\mathrm{Na} / \mathrm{K}$-ATPase in mouse trophectoderm. Dev Biol 141, 104-114 (1990)

68. Benos D.J, J.D. Biggers, R.S. Balaban, J.W. Mills, \& E.W. Overstrom: Developmental aspects of sodiumdependant transport processes of preimplantation rabbit embryos. In: Regulation and Development of Transport Processes Eds: Graves JS, John Wiley and Sons, New York, pp 211-236 (1985)

69. Benos D.J: Ouabain binding to preimplantation rabbit blastocysts. Dev Biol 83, 69-78 (1981)

70. Overstrom E.W, D.J. Benos, \& J.D. Biggers: Synthesis of Na/K-ATPase by the preimplantation rabbit blastocyst. $J$ Reprod Fertil 85, 283-295 (1989)

71. Betts D.H, D.J. MacPhee, G.M. Kidder, \& A.J. Watson: Ouabain Sensitivity and expression of $\mathrm{Na} / \mathrm{K}$-ATPase alphaand beta-subunit isoform genes during bovine early development. Mol Reprod Dev 46, 114-126 (1997)

72. Biggers J.D, R.M. Borland, \& C.P. LeChene: Ouabain sensitive fluid accumulation and ion transport by rabbit blastocysts. J Physiol 280, 319-330 (1978)

73. MacPhee D.J, K.J. Barr, P.A. De Sousa, S.D.L.Todd, \& G.M. Kidder: Regulation of Na/K-ATPase alpha subunit gene expression during mouse preimplantation development. Dev Biol 162, 259-266 (1994)

74. MacPhee D.J, D.H. Jones, K.J. Barr, D.H. Betts, A.J. Watson, \& G.M. Kidder: Differential involvements of $\mathrm{Na} / \mathrm{K}-\mathrm{ATPase}$ isozymes in preimplantation development of the mouse. Dev Biol 222, 486-498 (2000)

75. Dumoulin J.C, J.L. H. Evers, A.H. Michiels, M.H. Pieters, M. Bras, J.A.Land, \& J.P. Geriedts: Modulation of embryonic Na+-K+-ATPase activity and mouse preimplantation development in vitro in media containing high concentrations of potassium. Mol Reprod Dev 36, 320-327 (1993)

76. Magnuson T. J.B. Jacobson, \& C.W. Stackpole: Relationship between intercellular permeability and 
junction organization in the preimplantation mouse embryo. Dev Biol 67, 214-224 (1977)

77. McLaren A, \& R. Smith: Functional test of tight junctions in the mouse blastocyst. Nature 267, 351-353 (1977)

78. Ducibella T, \& E. Anderson: The effects of calcium deficiency on the formation of the zona occludens and blastocoel in the mouse embryo. Dev Biol 73, 46-58 (1979)

79. Fleming T.P: Trapped by a skeleton-the maintenance of epithelial membrane domains. BioEssays 7, 179-181 (1987)

80. Fleming T.P, \& M.H. Johnson: From egg to epithelium. Annu Rev Cell Biol 4, 459-485 (1988)

81. Fleming T.P, D.R. Garrod, \& A.J. Elsmore: Desmosome biogenesis in the mouse preimplantation embryo. Development 112, 527-539 (1991)

82. Fleming T.P, \& M.J. Hay: Tissue specific control of expression of the tight junction polypeptide $\mathrm{Z0}-1$ in the mouse early embryo. Development 113, 295-304 (1991)

83. Fleming T.P, P.D. Warren, P.D. Chisholm, \& M.H. Johnson: Trophectodermal processes regulate the expression of totipotency within the inner cell mass of the mouse expanding blastocyst. J Embryol exp Morphol 84, 63-90 (1984)

84. Fleming T.P, J. McConnell, M.H. Johnson, \& B.R. Stevenson: Development of tight junctions de novo in the mouse early embryo: control of assembly of the tight junction-specific protein, ZO-1. J Cell Biol 108, 1407-1418 (1989)

85. Damsky C.H, J. Richa, D. Solter, K. Knudsen, \& C.A. Buck: Identification and purification of a cell surface glycoprotein mediating intercellular adhesion in embryonic and adult tissue. Cell 34, 455-466 (1984)

86. Richa J, C.H. Damsky, C.A. Buck, B.B. Knowles, \& D. Solter: Cell surface glycoproteins mediate compaction, trophoblast attachment and endoderm formation during early mouse development. Dev Biol 108, 513-521 (1985)

87. Kemler R: From cadherins to catenins: cytoplasmic protein interactions and regulation of cell adhesion. Trends in Genetics 9, 317-321 (1993)

88. Johnson M.H, \& B. Maro: Time and space in the mouse early embryo: a cell biological approach to cell diversification. In: Experimental Approaches to Mammalian Embryonic Development. Eds: Rossant J, Pedersen RA, Cambridge University Press. New York, pp 35-66 (1986)

89. Kidder G.M: Intercellular communication during mouse embryogenesis. In: The Mammalian Preimplantation Embryo. Eds: Bavister BD. Plenum Press, New York, pp 43-64 (1987)
90. Vestweber D, A. Gossler, K. Boller, \& R. Kelmer: Expression and distribution of cell adhesion molecule uvomorulin in mouse preimplantation embryos. Dev Biol 124, 451-456 (1987)

91. Wiley L.M, \& M.F. Obasaju: Induction of cytoplasmic polarity in herterokaryons of mouse 4-cell-stage blastomeres fused with 8-cell and 16-cell-stage blastomeres. Dev Biol 130, 276-284 (1988)

92. Nuccitelli R, \& L.M. Wiley: Polarity of isolated blastomeres from mouse morulae: detection of transcellular ion currents. Dev Biol 109, 452-463 (1985)

93. Hoschuetzky H, H. Aberle, \& R. Kemler: Beta-catenin mediates the interaction of the cadherin-catenin complex with epidermal growth factor receptor. J Cell Biol 127, 1375-1380 (1994)

94. Huber O, C. Bierkamp, \& R. Kemler: Cadherins and catenins in development. Curr Opin Cell Biol 8, 685-691 (1996)

95. Gumbiner B, B. Stevenson, \& A. Grimaldi: The role of the cell adhesion molecule uvomorulin in the formation and maintenance of the epithelial junctional complex. J Cell Biol 107, 1575-1587 (1988)

96. Gumbiner B.M, \& P.D. McCrea: Catenins as mediators of the cytoplasmic functions of cadherins. J Cell Science 17,155-158 (1993)

97. Torres M, A. Stoykova, O. Huber, K. Chowdhury, P. Bonaldo, A. Mansouri, S. Butz, R. Kemler, \& P. Gruss: An alpha E-catenin gene trap mutation defines its function in preimplantation development. Proc Natl Acad Sci USA 94, 901-906 (1997)

98. McCrea, P.D, C.W. Turck, \& B. Gumbriner: A homologue of the armadillo protein in Drosophila (plakoglobin) associated with E-cadherin. Science 254, 1359-1361 (1991)

99. Hynes R.D: Specificity of cell adhesion in development: the cadherin superfamily. Curr Opin Genes Dev 2, 621-624 (1992)

100. Haegel H, L. Larue, M. Ohsugi, L. Fedorov, K. Herrenknecht,\& R. Kemler: Lack of beta-catenin affects mouse development at gastrulation. Development 121, 3529-3537 (1995)

101. Larue L, M. Ohsugi, J. Hirchenhain, \& R. Kelmer: Ecadherin null mutant embryos fail to form a trophectoderm epithelium. Proc Natl Acad Sci USA 91, 8263-8267 (1994)

102. Riethmacher D, V. Brinkman, \& C. Birchmeier: A targeted mutation in the mouse E-cadherin gene results in defective preimplantation development. Proc Natl Acad Sci USA 92, 855-859 (1995) 
103. Ohsugi M, L. Larue, H. Schwartz, \& R. Kemler: Cell-junctional and cytoskeletal organization in mouse blastocysts lacking E-cadherin. Dev Biol 185, 261-271 (1997)

104. Bierkamp C, K.J. Mclaughlin, H. Schwarz, O. Huber, \& R. Kemler: Embryonic heart and skin defects in mice lacking plakoglobin. Dev Biol 180, 780-785 (1996)

105. Bierkamp C, H. Schwarz, O. Huber, \& R. Kemler: Desmosomal localization of beta-catenin in the skin of plakoglobin null-mutant mice. Development 126, 371-381 (1999)

106. Guenet J.L, D. Simon-Chazottes, M. Ringwald, \& R. Kemler: The genes coding for alpha and beta catenin (Catnal and Catnab) and plakoglobin (Jup) map to mouse chromosomes 18, 9, and 11, respectively. Mamm Genome 6, 363-366 (1995)

107. Reuther G.W, \& C.J. Der: The Ras branch of small GTPases: Ras family members don't fall far from the tree. Curr Opin Cell Biol 12, 157-165 (2000)

108. Zhang B, Z.X. Wang, \& Y. Zheng: Characterization of the interactions between the small GTPase Cdc42 and its GTPase-activating proteins and putative effectors. $J$ Biol Chem 272, 21999-22007 (1997)

109. Kaibuchi K, S. Kuroda, M. Fukata, \& M. Nakagawa: Regulation of cadherin-mediated cell-cell adhesion by the Rho family GTPases. Curr Opinion Cell Biol 11, 591-596 (1999)

110. Kuroda S, M. Fukata, M. Nakagawa, \& K. Kaibuchi: Cdc42, Rac1, and their effecter IQGAP1 as molecular switches for cadherin-mediated cell-cell adhesion. Biochem Biophys Res Comm 262, 1-6 (1999)

111. Kuroda S, M. Fukata, K. Kobayashi, M. Nakafuku, N. Nomura, A. Iwamatsu, \& K. Kaibuchi: Identification of IQGAP as a putative target for the small GTPases, Cdc42 and Rac1. J Biol Chem 271, 23363-23367 (1996)

112. Aelst L.V, \& C. D'Souza-Schorey: Rho GTPases and signaling networks. Genes and Dev 11, 2295-2322 (1997)

113. Braga V.M, L.M. Machesky, A. Hall, \& N.A. Hotchin: The small GTPases Rho and Rac are required for the establishment of cadherin-dependent cell-cell contacts. J Cell Biol 137, 1421-1431 (1997)

114. Hall A: Rho GTPases and the actin cytoskeleton. Science 279, 509-514 (1998)

115. Nobes C.D, \& A. Hall: Rho GTPases control polarity, protrusion, and adhesion during cell movement. J Cell Biol $144,1235-1244$ (1999)

116. Fukata M, S. Kuroda, M. Nakagawa, A. Kawajiri, N. Itoh, I. Shoji, Y. Matsuura, S. Yonehara, H. Fujisawa, A. Kikuchi, \& K. Kaibuchi: Cdc42 and Rac1 regulate the interaction of IQGAP1 and beta-catenin. J Biol Chem 274, 26044-26050 (1999)

117. Hordijk P.L, J.P. ten Klooster, R.A. van der Kammen, F. Michiels, L.C.J.M. Oomen, \& J.C. Collard: Inhibition of invasion of epithelial cells by Tiam1-Rac signaling. Science 278, 1464-1466 (1997)

118. Adachi H, Y. Takahashi, T. Hasebe, M. Shirouzu, S. Yokoyama, \& K. Sutoh: Dictyostelium IQGAP-related protein specifically involved in the completion of cytokinesis. J Cell Biol 137, 891-898 (1997)

119. Aspenström P: Effectors for the Rho GTPases. Curr Opin Cell Biol 11, 95-102 (1999)

120. Li S, Q. Wang, A. Chaklader, R.T. Bronson, \& A. Bernards: Gastric hyperplasia in mice lacking the putative Cdc42 effector IQGAP1. Mol Cell Biol 20, 697-701 (2000)

121. McCallum S.J, W.J. Wu, \& R.A. Cerione: Identification of a putative effecter for $\mathrm{Cdc} 42 \mathrm{Hs}$ with high sequence similarity to the RasGAP-related protein IQGAP1 and a Cdc42Hs binding partner with similarity to IQGAP2. J Biol Chem 271, 21732-21737 (1996)

122. Vleminckx K, \& R. Kemler: Cadherins and tissue formation: integrating adhesion and signaling. BioEssays 21, 211-220 (1999)

123. Citi S: The molecular organization of tight junctions. J Cell Biol 121, 485-489 (1993)

124. Stevenson B.R, J.D. Siliciano, M.S. Mooseker, \& D.A. Goodenough: Identification of ZO-1: a high molecular weight polypeptide associated with the tight junction (zonula occludens) in a variety of epithelia. $J$ Cell Biol 103, 755-766 (1986)

125. Stevenson B.R, J. M. Anderson, \& S. Bullivant: The epithelial tight junction: structure, function and preliminary biochemical characterization. Mol Cell Biochem 83, 129145 (1988)

126. Citi S, H. Sabanay, R. Jakes, B. Geiger, \& J. Kendrick-Jones: Cingulin, a new peripheral component of tight junctions. Nature 333, 272-276 (1988)

127. Furuse M, T. Hirase, M. Itoh, A. Nagafuchi, S. Yonemura, S. Tsukita, \& S. Tsukita: Occludin: a novel integral membrane protein localizing at tight junctions. $J$ Cell Biol 123, 1777-1788 (1993)

128. Furuse M, K. Fujita, T. Hiiragi, K. Fujimoto, \& S. Tsukita: Claudin 1 and 2: novel integral membrane proteins localizing at tight junctions with no sequence similarity to occludin. J Cell Biol 141, 1539-1550 (1998)

129. Anderson J.M, B.R. Stevenson, L.A. Jesaitis, D.A. Goodenough, \& M.S. Mooseker: Characterization of ZO-1, a protein component of the tight junction from mouse liver 
and Madin-Darby canine kidney cells. J Cell Biol 106, 1141-1149 (1988)

130. Madden M.E, \& M.P. Sarras Jr: Development of an apical plasma membrane domain and tight junctions during histogenesis of the mammalian pancreas. Dev Biol 112, 427-442 (1985)

131. Madara J.L: Tight junction dynamics: is paracellular transport regulated? Cell 53, 497-498 (1988)

132. Barcroft L.C, A. Hay-Schmidt, A. Caveney, E. Gilfoyle, E. W. Overstrom, P. Hyttel, \& A.J. Watson: Trophectoderm differentiation in the bovine embryo: characterization of a polarized epithelium. J Reprod Fert 114, 327-339 (1998)

133. Fleming T.P, T. Papenbrock, I. Fesenko, P. Hausen, \& B. Sheth: Assembly of tight junctions during early vertebrate development. Semin Cell Dev Biol 11, 291-299 (2000)

134. Sheth B, I. Fesenko, J.E.. Collins, B. Moran, A.L. Wild, J.M. Anderson, \& T.P. Flemming: Tight junction assembly during mouse blastocyst formation is regulated by late expression of ZO-1 alphat isoform. Development 124, 2027-2037 (1997)

135. Sheth B, J. Fontaine, E. Ponza, A. McCallum, A. Page, S. Citi, D. Louvard, A. Zahraoui, \& T. Fleming: Differentiation of the epithelial apical junctional complex during mouse preimplantation development: a role for rab13 in the early maturation of the tight junction. Mech Dev 97, 93-104 (2000)

136. Blanco G, \& R.W. Mercer: Isozymes of the Na-KATPase: heterogeneity in structure, diversity and function. Am J Physiol 275, F633-F650 (1998)

137. Rizzolo L.J: Polarization of the $\mathrm{Na}+\mathrm{K}+\mathrm{ATPase}$ in epithelia derived from the neuroepithelium. Inter Rev Cyto $185,195-235$ (1999)

138. Ueno S, K. Takeda, S. Noguchi, \& M. Kawamura: Significance of the beta-subunit in the biogenesis of the Na+/K+-ATPase. Biosci Rep 17, 173-188 (1997)

139. Herrera V.L, J.R. Emanuel, N. Ruiz-Opazo, R. Levenson, \& B. Nadal-Ginard: Three differentially expressed $\mathrm{Na} / \mathrm{K}$-ATPase alpha-subunit isoforms: structural and functional implications. J Cell Biol 105, 1855-1865 (1987)

140. Kawakami K, H. Nojima, T. Ohta, \& K. Nagano: Molecular cloning and sequence analysis of human $\mathrm{Na}, \mathrm{K}$ ATPase beta-subunit. Nucleic Acids Res 14, 2833-44 (1986)

141. Mercer R.W, J.W. Schneider, A. Savitz, J. Emanuel, E.J. Benz Jr, \& R. Levenson Rat-brain Na/K-ATPase alpha-chain gene: primary structure, tissue specific expression, and amplification in ouabain-resistant HeLa C+ cells. Mol Cell Biol 6, 3884-3890 (1986)

142. Kent R.B, D.A. Fallows, E. Geissler, T. Glaser, J.R. Emanuel, P.A. Lalley, R. Levenson, \& D.E. Houseman: Genes encoding alpha and beta subunits of $\mathrm{Na} / \mathrm{K}$-ATPase are located on three different chromosomes in the mouse. Proc Natl Acad Sci USA 84, 5369-5373 (1987)

143. Schmalzing G, \& S. Gloor: Na+/K+-pump beta subunits: structure and function. Cell Physiol Biochem 4, 96-114 (1994)

144. Shamraj O.I, \& J.B. Lingrel: A putative fourth $\mathrm{Na} / \mathrm{K}$-ATPase alpha-subunit gene is expressed in testis. Proc Natl Acad Sci USA. 91, 12952-12956 (1994)

145. Geering K: The functional role of the beta subunit in the maturation and intracellular transport of $\mathrm{Na} / \mathrm{K}$-ATPase. FEBS Lett 285, 189-193 (1991)

146. Mercer R.W, D. Biemesderfer, D.P.. Bliss Jr, J.H. Collins, \& B. Forbush, III: Molecular cloning and immunological characterization of the gamma polypeptide, a small protein associated with the $\mathrm{Na} / \mathrm{K}$-ATPase. J Cell Biol 121, 579-586 (1993)

147. Beguin P, X. Wang, D. Frisev, A. Puoti, D. Claeys, J.D. Harisberger, K. Geering: The gamma-subunit is a specific components of the $\mathrm{Na} / \mathrm{K}$-ATPase and modulates its transport function. EMBO J 16, 4250-4260 (1997)

148. Jones D.H, T.C. Davies, \& G.M. Kidder: Embryonic expression of the putative gamma-subunit of the sodium pump is required for acquisition of fluid transport capacity during mouse blastocyst development. J Cell Biol 139, 1545-1552 (1997)

149. Horisberger J.D: Inhibitors of the sodium pump: toxins, then drugs and now hormones. Arch Toxicol Suppl 17, 116-124 (1995)

150. Collins J, \& J. Leszyk: The "gamma subunit" of Na,K-ATPase: a small amphiphilic protein with a unique amino acid sequence. Biochemistry 26, 8665-8668 (1987)

151. Shull G.E, J. Greeb, \& J. B. Lingrel: Molecular cloning of three distinct forms of the Na/K-ATPase alphasubunit from rat brain. Biochemistry 25, 8125-8132 (1986)

152. Shull G.E, \& J.B. Lingrel: Multiple genes encode the human Na/K-ATPase catalytic subunit. Proc Natl Acad Sci USA 84, 4039-4043 (1987)

153. Young R.M, \& J.B. Lingrel: Tissue distribution of mRNAs encoding the alpha isoforms and beta subunit of rat Na/K-ATPase. Biochem Biophys Res Comm 145, 52-58 (1987)

154. Magyar J.P, U. Bartsch, Z-Q. Wang, N. Howells, A. Aguzzi, E.F. Wagner, M. Schachner: Degeneration of neural cells in the central nervous system of mice deficient 
in the gene for the adhesion molecule on glia, the beta 2 subunit of murine Na,K-ATPase. J Cell Biol 127, 835-845 (1994)

155. Malik N, V.A. Canfield, M-C. Beckers, P. Gros, \& R. Levenson: Identification of the mammalian Na,K-ATPase beta 3 subunit. J Biol Chem 271, 22754-22758 (1996)

156. Shyjan A.W, C. Gottardi, \& R. Levenson: The Na/KATPase beta 2 subunit is expressed in rat brain and copurifies with Na/K-ATPase activity. J Biol Chem 265, 5166-5169 (1990)

157. Crambert G, U. Hasler, A.T. Beggah, C. Yu, N.N. Modyanov, J-D. Horisberger, L. Lelievre, \& K. Geering: Transport and pharmacological properties of nine different human Na/K-ATPase isozymes. J Biol Chem 275, 19761986 (2000)

158. Ewart H.S, \& A. Klip: Hormonal regulation of the Na+-K+-ATPase: Mechanisms underlying rapid and sustained changes in pump activity. Am J Physiol 269, C295-311 (1995)

159. Rossier B.C, K. Geering, \& J-P. Kraehenbuhl: Regulation of the sodium pump: how and why? Trends Biochem Sci 12, 483-7 (1987)

160. Wang Z-M, M. Yasui, \& G. Celsi: Glucocorticoids regulate the transcription of $\mathrm{Na}+\mathrm{K}+-\mathrm{ATPase}$ genes in the infant rat kidney. Am J Physiol 267, C450-5 (1994)

161. Marver D: Regulation of $\mathrm{Na}+\mathrm{K}+-\mathrm{ATPase}$ by aldosterone. Sem Nephrol 12, 56-61 (1992)

162. Marakhova I.I, A.A. Vereninov, F.V. Toropova, T.A. Vinogradova: Long-term enhancement of Na,K-ATPase pump during blast transformation of human lymphocytes is controlled first by translational, then by transcriptional mechanisms. FEBS Letters 368, 110-2 (1995)

163. Giunta C, M. Cavaletto, L. Pergola, E. Pessione, \& P. Bracchino: Modulation of $\mathrm{Na}+\mathrm{K}+$ pump in intact erythrocytes by cardioglycosides, steroid hormones and ouabain-like compounds. Gen Pharm 23, 683-7 (1992)

164. Pressley T.A, F. Ismail-Beigi, G.G. Gick, \& I.S. Edelman: Increased abundance of $\mathrm{Na} / \mathrm{K}$-ATPase mRNAs in response to low external K+. Am J Physiol 255, C252-C260 (1988)

165. Ismail-Beigi $\mathrm{F}$ : Regulation of $\mathrm{Na}+, \mathrm{K}+-\mathrm{ATPase}$ expression by thyroid hormone. Sem Nephrol 12, 44-8 (1992)

166. Mujais S.K, N.A. Nora, \& Y. Chen: Regulation of the renal $\mathrm{Na} / \mathrm{K}$ pump: Role of progesterone. J Amer Soc Nephrol 3, 1488-95 (1993)

167. Beguin P, M. C. Peitsch, \& K. Geering: alpha 1 but not alpha 2 or alpha 3 isoforms of $\mathrm{Na} / \mathrm{K}$-ATPase are efficiently phosphorylated in a novel protein kinase C motif. Biochemistry 35, 14098-14108 (1996)

168. Lucking K, J.M. Nielson, P.A. Pedersen, \& P.L. Jorgensen: $\mathrm{Na} / \mathrm{K}-A T P a s e$ isoforms (alpha 3, alpha 2 , alpha 1) abundance in rat kidney estimated by competitive RTPCR and ouabain binding. Am J Physiol 271, F253-F260 (1996)

169. Jewell E.A, \& J.B. Lingrel: Comparison of the substrate dependence properties of the rat $\mathrm{Na} / \mathrm{K}$-ATPase alpha 1 , alpha 2 and alpha 3 isoforms expressed in Hela cells. J Biol Chem 266, 16925-16930 (1991)

170. Blanco G, J.C. Koster, G. Sanchez, \& R.W. Mercer: Kinetic properties of the alpha2beta1 and alpha 2 beta 2 isozymes of the $\mathrm{Na} / \mathrm{K}-\mathrm{ATPase}$. Biochemistry 34, 319-325 (1995)

171. Blanco G, G. Sanchez, \& R.W. Mercer: Comparison of the enzymatic properties of the $\mathrm{Na} / \mathrm{K}$-ATPase alpha 3 beta 1 and alpha 3 beta 2 isozymes. Biochemistry 34, 98979903 (1995)

172. Freschenko M.S, \& K.J. Sweadner: Structural basis for species-specific differences in the phosphorylation of $\mathrm{Na} / \mathrm{K}$-ATPase by protein kinase C. J Biol Chem 270, 14072-14077 (1995)

173. Daly S.E, L.K. Lane, \& R. Blostein: Structure/function analysis of the amino-terminal region of the alpha 1 and alpha 2 subunits of $\mathrm{Na} / \mathrm{K}$-ATPase. $J$ Biol Chem 271, 23683-23689 (1996)

174. Daly S.E, L.K. Lane, \& R. Blostein: Functional consequences of amino-terminal diversity of the catalytic subunit of the Na/K-ATPase. J Biol Chem 269, 2394423948 (1994)

175. Munzer J.S, S.E. Daly, E.A. Jewell-Motz, J.B. Lingrel, \& R. Blostein: Tissue- and isoform-specific kinetic behavior of the Na/K-ATPase. J Biol Chem 269, 1666816676 (1994)

176. Ducibella T, T. Ukena, M. Karnovsky, \& E. Anderson: Changes in cell surface and cortical cytoplasmic organization during early embryogenesis in the preimplantation mouse embryo. J Cell Biol 74, 153-167 (1977)

177. Stekhoven F.S, \& S.L. Bonting: Transport adenosine triphosphatases: properties and functions. Physiol Rev 61, 1-76 (1981)

178. Gardiner C.S, J.S. Williams, \& A.R. Menino: Sodium/Potassium adenosine triphosphatase alpha- and beta-subunit and alpha-subunit mRNA levels during mouse embryo development in vitro. Biol Reprod 43, 788-794 (1990a)

179. Emanuel J.R, S. Garetz, L. Stone, \& R. Levenson: Differential expression of $\mathrm{Na} / \mathrm{K}$-ATPase alpha and beta 
subunit mRNAs in rat tissues and cell lines. Proc Natl Acad Sci USA 84, 9030-9034 (1987)

180. Schneider J.W, R.W. Mercer, M. Gilmore-Herbert, M. F. Utset, C. Lai, A. Greene, \& E.J. Benz, Jr: Tissue specificity, localization in brain and cell free translation of mRNA encoding the alpha 3 isoform of $\mathrm{Na} / \mathrm{K}$-ATPase. Proc Natl Acad Sci USA 85, 284-288 (1988)

181. Orlowiski J, \& J.B. Lingrel: Differential expression of the $\mathrm{Na} / \mathrm{K}$-ATPase alpha 1 and alpha 2 subunit genes in a murine myogenic cell line. J Biol Chem 263, 17817-17821 (1988b)

182. Orlowiski J, \& J.B. Lingrel: Tissue specific and developmental regulation of rat $\mathrm{Na} / \mathrm{K}$-ATPase catalytic alpha isoform and beta subunit mRNAs. J Biol Chem 263, 10436-10442 (1988a)

183. Watson A.J, A. Hogan, A. Hahnel, \& G.A. Schultz: Activation of the embryonic genome:comparisons between mouse and bovine development. In: Proceedings of the Serono Symposium on Preimplantation Embryo Development. Eds: Bavister BD, Springer-Verlag, New York. (1992b)

184. Shyjan A.W, \& R. Levenson: Antisera specific for the alpha 1, alpha 2 , alpha 3 and beta subunits of the $\mathrm{Na} / \mathrm{K}$ ATPase: differential expression of alpha and beta subunits in rat tissue membranes. Biochemistry 28, 4531-4535 (1989)

185. Hara Y, A. Nikamoto, T. Kojima, A. Matsumoto, \& M. Nakao: Expression of sodium pump activities in BALB/c3T3 transfected with cDNA encoding alpha 3subunits of rat brain Na/K-ATPase. FEBS Lett 238, 27-30 (1988)

186. Fallows D, R.B. Kent, D.L. Nelson, J.R. Emanuel, R. Levenson, R. \& D.E. Houseman: Chromosome-mediated transfer of the murine $\mathrm{Na} / \mathrm{K}$-ATPase alpha-subunit confers ouabain resistance. Mol Cell Biol 7, 2985-2987 (1987)

187. Levenson R, V. Racaniello, L. Albritton, \& D. Houseman: Molecular cloning of the mouse ouabainresistance gene. Proc Natl Acad Sci USA 81, 1489-1493 (1984)

188. Geering K, J. Kraehenbuhl, \& B.C. Rossier: Maturation of the catalytic alpha-subunit of Na/K-ATPase during intracellular transport. J Cell Biol 105, 2613-2619 (1987)

189. Geering K: Posttranslational modifications and intracellular transport of sodium pumps: importance of subunit assembly. Soc Gen Physiol Ser 46, 31-43 (1991a)

190. McDonough A.A, K. Geering, \& R.A. Farley: The sodium pump needs its beta subunit. FASEB 4, 1598-1605 (1993)
191. Caplan M.J, H.C. Anderson, G.E. Palade, \& J.D. Jamieson: Intracellular sorting and polarized cell surface delivery of $\mathrm{Na} / \mathrm{K}$-ATPase, an endogenous component of MDCK cell basolateral plasma membranes. Cell 46, 623631 (1986)

192. Villalobos A.R, J.T. Parmelee, \& J.B. Pritchard: Functional characterization of choroid plexus epithelial cells in primary culture. J Pharmacol Exp Ther 282, 11091116 (1997)

193. Just F, \& B. Walz: Immunocytochemical localization of $\mathrm{Na} / \mathrm{K}$-ATPase and V-H -ATPase in the salivary glands of the cockroach, periplaneta americana. Cell Tissue Res 278, 161-170 (1994)

194. Zahler R, Z.T. Zhang, M. Manor, W.F. Boron: Sodium kinetics of $\mathrm{Na} / \mathrm{K}$-ATPase alpha isoforms in intact transfected HELA cells. J Gen Physiol 110, 201-213 (1997)

195. James P.F, I.L. Grupp, G. Grupp, A.L. Woo, G.R. Askew, M.L.Croyle, R.A. Walsh, \& J.B. Lingrel: Identification of a specific role for the $\mathrm{Na} / \mathrm{K}$-ATPase alpha2 isoform as a regulator of calcium in the heart. Mol Cell 3, 555-563 (1999)

196. Zeuthen T: Molecular mechanisms for passive and active transport of water. Inter Rev Cyto 160, 99-161 (1995)

197. Wintour E.M: Water channels and urea transporters. Clin Exper Pharm Physiol 24, 1-9 (1997)

198. Spring K.R. Routes and mechanism of fluid transport by epithelia. Ann Rev Physiol. 60, 105-119 (1998)

199. Zeidel M.L: Low permeabilities of apical membranes of barrier epithelia: what makes watertight membranes watertight. Am J Physiol 271(40), F243-F245 (1996)

200. Verkman A.S: Lessons on renal physiology from transgenic mice lacking aquaporin water channels. $J \mathrm{Am}$ Soc Nephrol 10, 1126-1135 (1999)

201. Borgnia M, S. Nielson, A. Engel, \& P. Agre: Cellular and molecular biology of the aquaporin water channels. Annu Rev Biochem 68, 425-458 (1999)

202. Dainty J: Osmotic flow. Symp Soc Exp Biol 19, 75-85 (1965)

203. Paganelli C.V, \& A.K. Solomon: The rate of exchange of tritiated water across the human red blood cell membrane. J Gen Physiol 41, 259-277 (1957)

204. Harris H.W. Jr, \& M.L. Zeidal: Water channels. Curr Opin Nephrol Hypertens 2, 699-707 (1993)

205. Mulders S.M, A.F. van Lieburg, L.A.H. Monnens, N.V.A.M. Knoers, P.M.T. Deen, \& C.H. van OS: Physiology and pathophysiology of aquaporins. Eur J Clin Invest 26, 1041-1050 (1996) 
206. Lee M.D, L.S. King, \& P. Agre: The aquaporin family of water channel proteins in clinical medicine. Medicine 76, 141-156 (1997)

207. Deen P.M.T, \& C.H. van Os: Epithelial aquaporins. Cur Opin Cell Biol 10, 435-442 (1998)

208. Zeidel M.L: Recent advances in water transport. Sem Nephro 18, 167-177 (1998)

209. Agre P: Molecular physiology of water transport: aquaporin nomenclature workshop on mammalian aquaporins. Biol Cell 89, 255-257 (1997)

210. Holtug K, M.B. Hansen, \& E. Skadhauge: Experimental studies of intestinal ion and water transport. Scand J Gastroentrol 31, 95-110 (1996)

211. Parisi M, M. Pisam, G. Calamita, R. Gobin, R. Toriano, \& J. Bourguet: Water pathways across a reconstituted epithelial barrier formed by Caco- 2 cells: effects of medium hypertonicity. J Membr Biol 143, 237245 (1995)

212. Fettiplace R, \& D.A. Haydon: Water permeability of lipid membranes. Physiol Rev 60, 510-550 (1980)

213. Finkelstein A: Water movement through lipid bilayers, pores and plasma membranes: theory and reality. New York: Wiley (1986)

214. Folkesson H.G, M.A. Matthay, H. Hasegawa, F. Kheradmand, \& A.S. Verkman: Transcellular water transport in lung alveolar epithelium through mercurysensitive water channels. Proc Natl Acad Sci USA 91, 4970-4974 (1994)

215. Shiels A, \& C.S. Griffin: Aberrant expression of the gene for lens major intrinsic protein in the CAT mouse. Curr Eye Res 12, 913-921 (1993)

216. Echevarria M, F.E. Windhager, S.S. Tate, \& G. Frindt: Cloning and expression of AQP1 a water channel from the medullary collecting duct of rat kidney. Proc Natl Acad Sci USA 91, 10997-11001 (1994)

217. Yang B, \& A.S. Verkman: Water and glycerol permeabilities of aquaporins 1-5 and MIP determined quantitatively by expression of epitope-tagged constructs in Xenopus oocytes. J Biol Chem 272, 16140-16148 (1997)

218. Heymann J.B, P. Agre, \& A. Engel: Progress on the structure and function of aquaporin 1. J Struct Biol 121, 191-206 (1998)

219. Yang B, H.G. Folkesson, J. Yang, M.A. Matthay, T. Ma, \& A.S. Verkman: Reduced osmotic water permeability of the peritoneal barrier in aquaporin -1 knockout mice. $A m$ J Physiol 276(45), C76-C81 (1999)
220. Fushimi K, S. Uchida, Y. Hara, Y. Hirata, F. Marumo, \& S. Sasaki: Cloning and expression of apical membrane water channel of rat kidney collecting tubule. Nature 361, 549-552 (1993)

221. Katsura T, D.A. Ausiello, \& D. Brown: Direct demonstration of aquaporin-2 water channel recycling in stably transfected LLC-PK1 epithelial cells. Am J Physiol 270, F548-F553 (1996)

222. Sasaki S, K. Ishibashi, \& F. Marumo: Aqaporin-2 and -3: representatives of two subgroups of the aquaporin family colocalized in the kidney collecting duct. Annu Rev Physiol 60, 199-220 (1998)

223. Van Lieburg A.F, M.A. Verdijk, V.V. Knoers, A.J. van Essen, W. Proesmans, R. Malimann, L.A. Monnens, B.A. van Oost, C.H.. van Os, \& P.M. Deen: Patients with autosomal nephrogenic diabetes insipidus homozygous for mutations in the aquaporin 2 water channel gene. Am J Hum Genet 55, 648-652 (1994)

224. Ishibashi K, M. Kuwahara, Y. Gu, Y. Tanaka, F. Marumo, \& S. Sasak,i: Cloning and functional expression of a new aquaporin (AQP9) abundantly expressed in the peripheral leukocytes permeable to water and urea but not to glycerol. Biochem Biophys Res Comm 244, 268-274 (1998)

225. Inase N, K. Fushimi, K. Ishibashi, S. Uchida, M. Ichioka, S. Sasaki, \& F. Marumo: Isolation of human aquaporin 3 gene. J Biol Chem 270, 17913-17916 (1995)

226. Jung J.S, R.V. Bhat, G.M. Preston, W.B. Guggino, J.M. Baraban, \& P. Agre: Molecular characterization of an aquaporin cDNA from brain: candidate osmoreceptor and regulator of water balance. Proc Natl Acad Sci USA 91, 13052-13056 (1994)

227. Hasegawa H, T. Ma, W. Skach, M.A. Matthay, A.S. Verkman: Molecular cloning of a mercury-insensitive water channel expressed in selected water transporting tissues. J Biol Chem 269, 5497-5500 (1994)

228. Terris J, C.A. Ecelbarger, D. Marples, M.A. Knepper, S. Nielsen: Distribution of aquaporin-4 water channel expression within rat kidney. Am J Physiol 38, F775-F785 (1995)

229. Bai C, N. Fukuda, Y. Song, T. Ma, M.A. Matthay, \& A.S. Verkman: Lung fluid transport in aquaporin-1 and aquaporin-4 knockout mice. J Clin Invest 103, 555-561 (1999)

230. Ма T, B. Yang, A. Gillespie, E.J. Carlson, C.J. Epstein, \& A.S. Verkman: Generation and phenotype of a transgenic knockout mouse lacking the mercurialinsensitive water channel aquaporin-4. J Clin Invest 100, 957-962 (1997) 
231. Ma T, B. Yang, \& A.S. Verkman: Gene structure, cDNA cloning and expression of a mouse mercurialinsensitive water channel. Genomics 33, 382-388 (1996)

232. Raina S, G.M. Preston, W.B. Guggino, \& P. Agre: Molecular cloning and characterization of an aquaporin cDNA from salivary, lacrimal and respiratory tissues. $J$ Biol Chem 270, 1908-1912 (1995)

233. Ma T, Y. Song, A. Gillespie, E.J. Carlson, C.J. Epstein, \& A.S. Verkman: Defective secretion of saliva in transgenic mice lacking aquaporin-5 water channels. J Biol Chem 274, 20071-20074 (1999)

234. Yasui M, A. Hazama, T.H. Kwon, S. Nielsen, W.B. Guggino, \& P. Agre: Rapid gating and anion permeability of an intracellular aquaporin. Nature 402, 184-187 (1999)

235. Ishibashi K, S. Sasaki, K. Fushimi, S. Uchida, M. Kuwahara, H. Saito, T. Furukawa, K. Nakajima, Y. Yamaguchi, T. Gojobori, \& F. Marumo: Molecular cloning and expression of a member of the aquaporin family with permeability to glycerol and urea in addition to water expressed at the basolateral membrane of kidney collecting duct cells. Proc Natl Acad Sci USA 91, 6269-6273 (1994)

236. Ma T, B. Yang, \& A.S. Verkman: Cloning of a novel water and urea-permeable aquaporin from mouse expressed strongly in colon, placenta, liver and heart. Biochem Biophys Res Comm 240, 324-328 (1997)

237. Koyama Y, T. Yamamoto, D. Kondo, H. Funaki, E. Yaoita, K. Kawasaki, N. Sato, K. Hatakeyama, \& I. Kihara: Molecular cloning of a new aquaporin from rat pancreas. $J$ Biol Chem 272, 30329-30333 (1997)

238. Ishibashi K, M. Kuwahara, Y. Kageyama, A. Tohsaka, F. Marumo, \& S. Sasaki: Cloning and functional expression of a second new aquaporin abundantly expressed in testis. Biochem Biophys Res Comm 237, 714718 (1997)

239. Edashige K, M. Sakamoto, \& M. Kasai: Expression of mRNAs of the aquaporin family in mouse oocytes and embryos. Cryobiology 40, 171-175 (2000)

240. Offenberg H, L.C. Barcroft, A. Caveney, D. Viuff, P.D. Thomsen, \& A.J. Watson: mRNAs encoding aquaporins are present during murine preimplantation development. Mol Reprod Dev 57,1-8 (2000)

241. Barker D.J.P: Mothers, babies and disease in later life. BMJ Publishing group. London, England (1994)

242. Bowen J.R., F.L. Gibson, G.I. Leslie, \& D.M. Saunders: Medical and developmental outcome at 1 year for children conceived by intracytoplasmic sperm injection. Lancet 351:1529-1534 (1998)

Key Words Oocyte, Cavitation, Compaction, Preimplantation Development, Gene Expression, Review
Send correspondence to: $\mathrm{Dr}$ Andrew J. Watson, Department of Physiology, Rm 238 Medical Sciences Bldg The University of Western Ontario, London, Ontario Canada, N6A 5C1, Tel: 519-661-3467, Fax (519) 661-3827

E-mail: andrew.watson@med.uwo.ca 